Prepared in cooperation with

Montgomery County, Maryland

Prince George's County, Maryland

Water Quality in the Anacostia River, Maryland and Rock Creek, Washington, D.C.: Continuous and Discrete Monitoring with Simulations to Estimate Concentrations and Yields of Nutrients, Suspended Sediment, and Bacteria

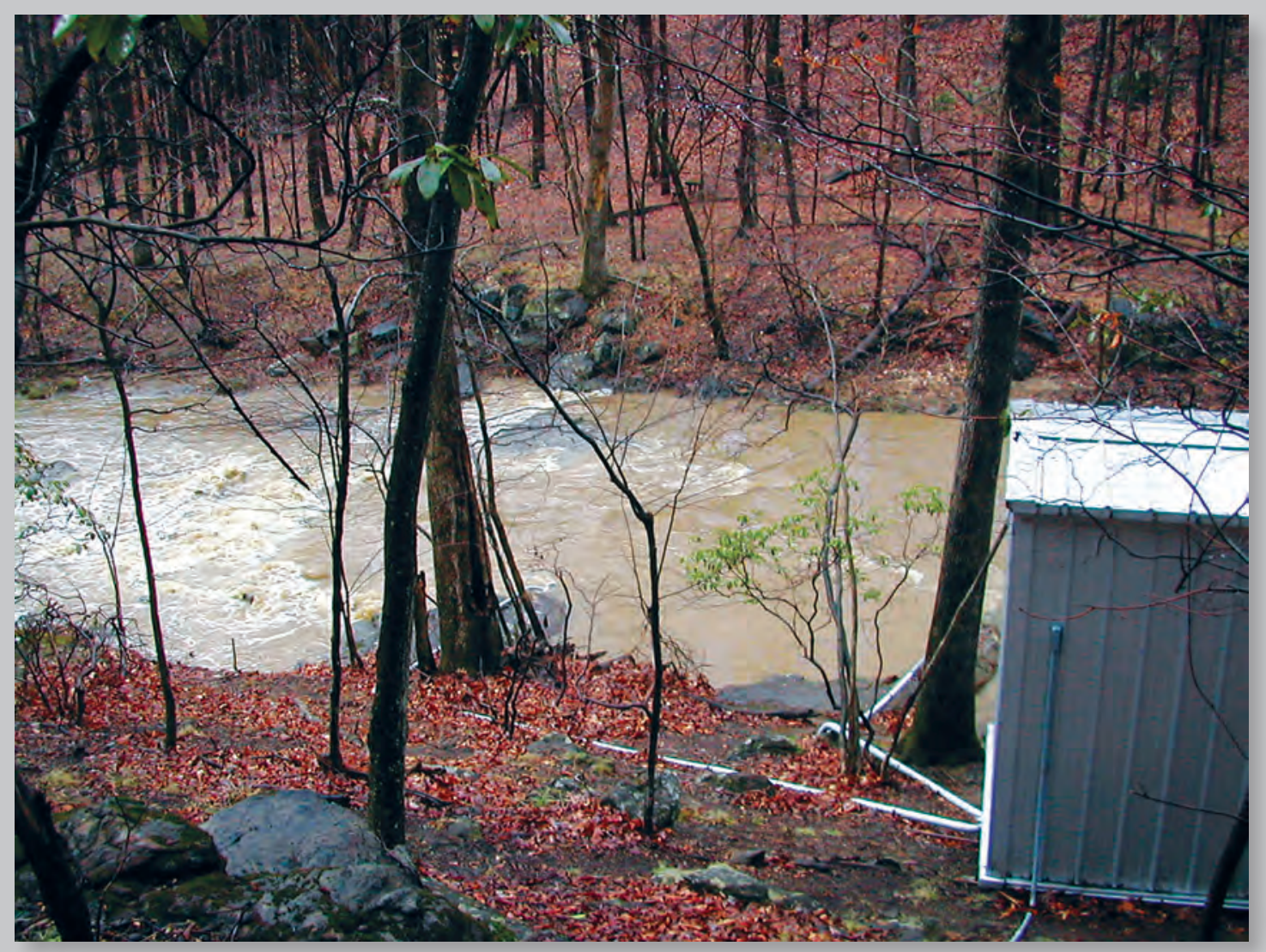

Open-File Report 2013-1034 
Cover. View of water-quality monitoring station at Paint Branch near College Park, Maryland (USGS station 01649190). Photograph by U.S. Geological Survey. 


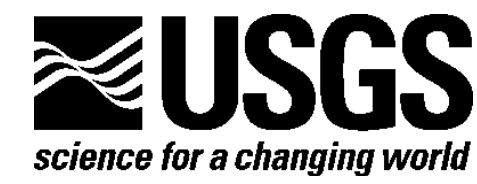

Prepared in cooperation with

Montgomery County, Maryland

Prince George's County, Maryland

\section{Water Quality in the Anacostia River, Maryland and Rock Creek, Washington, D.C.: Continuous and Discrete Monitoring with Simulations to Estimate Concentrations and Yields of Nutrients, Suspended Sediment, and Bacteria}

By Cherie V. Miller, Jeffrey G. Chanat, and Joseph M. Bell

Open-File Report 2013-1034

U.S. Department of the Interior

U.S. Geological Survey 


\section{U.S. Department of the Interior KEN SALAZAR, Secretary}

\section{U.S. Geological Survey \\ Suzette M. Kimball, Acting Director}

U.S. Geological Survey, Reston, Virginia: 2013

For more information on the USGS-the Federal source for science about the Earth, its natural and living resources, natural hazards, and the environment-visit http://www.usgs.gov or call 1-888-ASK-USGS

For an overview of USGS information products, including maps, imagery, and publications, visit http://www.usgs.gov/pubprod

To order this and other USGS information products, visit http://store.usgs.gov

\section{Suggested citation:}

Miller, C.V., Chanat, J.G., and Bell, J.M., 2013, Water quality in the Anacostia River, Maryland and Rock Creek, Washington, D.C.: Continuous and discrete monitoring with simulations to estimate concentrations and yields of nutrients, suspended sediment, and bacteria: U.S. Geological Survey Open-File Report 2013-1034, 37 p.

Any use of trade, product, or firm names is for descriptive purposes only and does not imply endorsement by the U.S. Government.

Although this report is in the public domain, permission must be secured from the individual copyright owners to reproduce any copyrighted material contained within this report. 


\section{Contents}

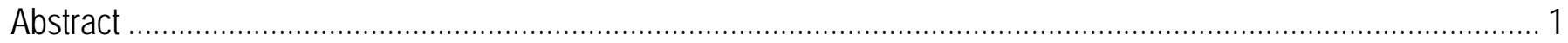

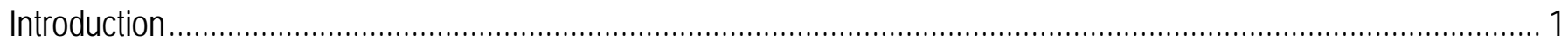

Purpose and Scope

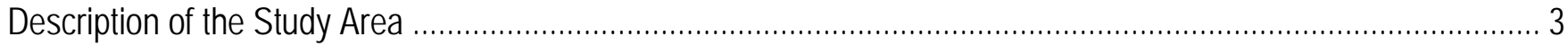

Methods

Measurements of Stream Discharge and Continuous Water Quality …....................................................... 6

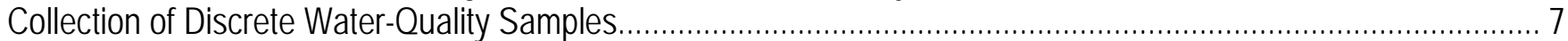

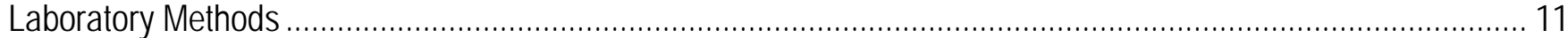

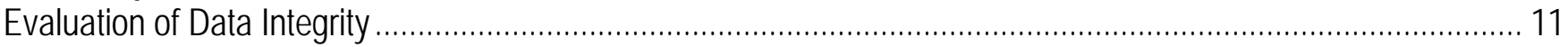

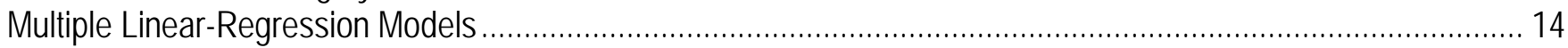

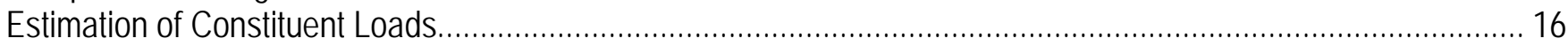

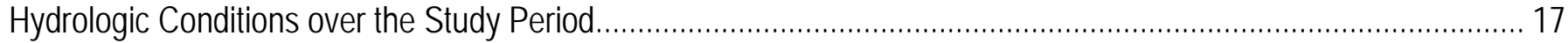

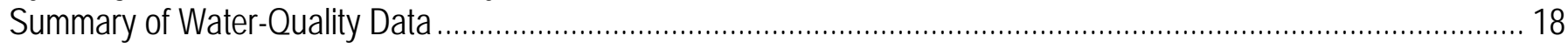

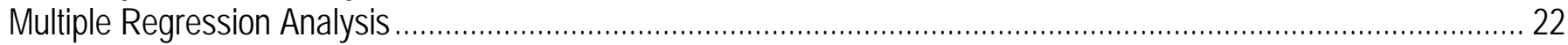

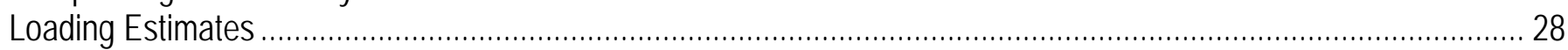

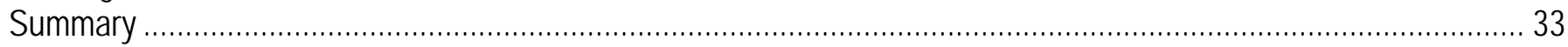

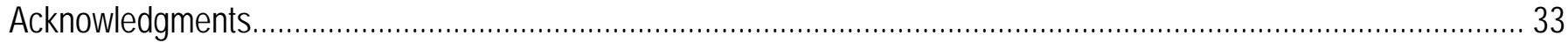

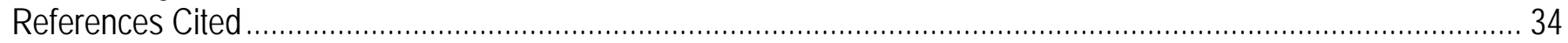

\section{Figures}

Figure 1. Map showing locations of the Anacostia River and Rock Creek watersheds and U.S. Geological Survey monitoring stations used in this study [Northeast Branch Anacostia River at Riverdale, Maryland (01649500), Northwest Branch Anacostia River near Hyattsville, Maryland (01651000), Paint Branch near College Park, Maryland (01649190), Rock Creek at Joyce Road, Washington, D.C. (01648010) and Rock Creek at Sherrill

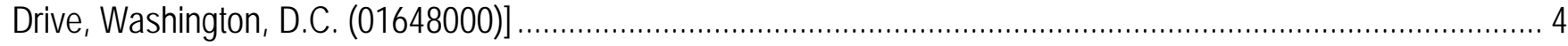

Figure 2. Photographs showing collection of water-quality samples using equal-width-increment (EWI) sampling: (A) collecting depth-integrated subsamples at equal-width intervals across the stream cross section; (B) compositing and collecting subsamples from a churn splitter in a clean van; and (C) collecting an integrated EWI sample with a $\mathrm{DH}-95$ sampling device from a bridge

Figure 3. Photographs showing (A) automatic sampler with (B) data logger. The system records physical parameters from (C) a datasonde deployed in the stream, uploads data via satellite to the worldwide web, and triggers the automatic sampler at a selected gage height to collect water-quality samples over a storm hydrograph 9 Figure 4. Graphs showing duration curves for (A) discharge, (B) water temperature, and (C) turbidity at Paint Branch near College Park, Maryland (USGS station 01649190) over the period of study. The ranges of flow conditions over which equal-width-increment (EWI) and automatic-sampler samples were collected are plotted on the duration curves.

Figure 5. Scatter plot comparing specific conductance to discharge at Paint Branch near College Park, Maryland (USGS station 01649190) during the study period showing the effects of road salt and the cutoff value of 350 microsiemens per centimeter for model censoring. ................................................................................ 15 Figure 6. Boxplots comparing monthly summaries of 15-minute-interval discharge data for the Northeast Branch Anacostia River (USGS station 01649500) for water years 2004 through 2011.

Figure 7. Boxplots comparing monthly summaries of discrete water-quality data for Paint Branch near College Park, Maryland (USGS station 01649190) for water years 2008 to 2011. Concentrations of (A) suspended sediment 
in milligrams per liter, (B) total nitrogen in milligrams per liter, (C) total phosphorus in milligrams per liter, and (D) $E$. coli in most probable number of viable colony-forming units per 100 milliliters

Figure 8. Scatter plots comparing continuous physical parameters and discrete water quality for Paint Branch near College Park, Maryland (USGS station 01649190), including all data from automatic samplers and equal-width increment (EWI) sampling, showing correlations and spread for each relation. Simple least-square fits to the data are drawn for each plot

Figure 9. Time-series plots comparing estimated and measured concentrations of $(A, B)$ suspended sediment, $(C, D)$ total nitrogen, $(E, F)$ total phosphorus, and $(G, H) E$. coli with an overlay of discharge during two storm events for Paint Branch near College Park, Maryland (USGS station 01649190).

Figure 10. Scatter plots comparing estimated and observed concentrations of (A) suspended sediment, (B) total nitrogen, (C) total phosphorus, and (D) E. coli for Paint Branch near College Park, Maryland (USGS station 01649190), using the model equations and bias corrections provided in table 9.

\section{Tables}

Table 1. Percentages of land cover in the watersheds above U.S. Geological Survey monitoring stations: Northeast Branch Anacostia River at Riverdale, Maryland (01649500); Northwest Branch Anacostia River near Hyattsville, Maryland (01651000); Paint Branch near College Park, Maryland (01649190); and Rock Creek at Joyce Road, Washington, D.C. (01648010)......

Table 2. Periods of record for discharge and water-quality data that are summarized in this report for Northeast Branch Anacostia River at Riverdale, Maryland (01649500), Northwest Branch Anacostia River near Hyattsville, Maryland (01651000), Paint Branch near College Park, Maryland (01649190), Rock Creek at Joyce Road, Washington, D.C. (01648010, water quality only), and Rock Creek at Sherrill Drive, Washington, D.C. (01648000,

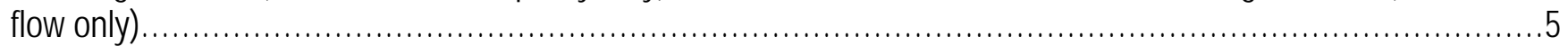

Table 3. Summary of potential bias from all field and automatic-sampler blanks for the $90^{\text {th }}$ percentile of

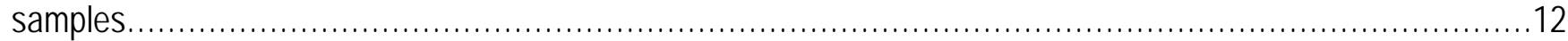

Table 4. Summary of sampling and analytical precision determined by field replicates............................... 14

Table 5. Top eight daily mean discharge events for the Northeast Branch Anacostia River at Riverdale, Maryland (USGS station 01649500) for water years 2004-2011.......................................................... 18

Table 6. Summaries of continuous field parameters for each of the U.S. Geological Survey stations in the Anacostia River and Rock Creek watersheds

Table 7. Summaries of discrete water-quality data for each of the U.S. Geological Survey stations in the Anacostia River and Rock Creek collected over the study period.

Table 8. Table of Pearson correlation coefficients for Paint Branch near College Park, Maryland (USGS station

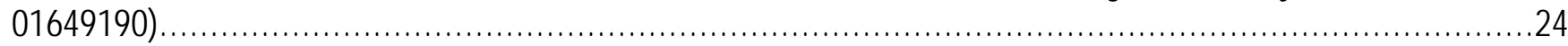

Table 9. Summary of regression models for the Northeast (NE) Branch Anacostia River at Riverdale, Maryland (USGS station 01649500), the Northwest (NW) Branch Anacostia River near Hyattsville, Maryland (USGS station 01651000), and Paint Branch near College Park, Maryland (USGS station 01649190).

Table 10. Summary of annual loads for suspended sediment, total nitrogen, total phosphorus, and bacteria for the Anacostia River at three stations: Northeast Branch Anacostia River at Riverdale, Maryland (USGS station 01649500); Northwest Branch Anacostia River near Hyattsville, Maryland (01651000); Paint Branch near College Park, Maryland (01649190); and for one combined station on Rock Creek: Rock Creek at Joyce Road, Washington, D.C. (01648010, for water quality) and Rock Creek at Sherrill Drive, Washington, D.C. (01648000, for flow).

Table 11. Estimates of annual yields (loads per square area) for suspended sediment, total nitrogen, total phosphorus, and E. coli for the Anacostia River (USGS stations 01649190, 01649500, and 01651000) and Rock 
Creek (USGS stations 01648010 (water quality) and 01648000 (flow) for data collected variously in water years

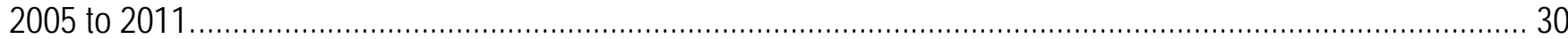
Table 12. Comparison of estimates of yields for the Northeast and Northwest Branches Anacostia River from different studies. 


\section{Conversion Factors}

\begin{tabular}{|c|c|c|}
\hline Multiply & By & To obtain \\
\hline \multicolumn{3}{|c|}{ Length } \\
\hline centimeter $(\mathrm{cm})$ & 0.3937 & inch (in.) \\
\hline meter (m) & 3.281 & foot $(\mathrm{ft})$ \\
\hline kilometer (km) & 0.6214 & mile (mi) \\
\hline \multicolumn{3}{|c|}{ Area } \\
\hline square kilometer $\left(\mathrm{km}^{2}\right)$ & 247.1 & acre \\
\hline square kilometer $\left(\mathrm{km}^{2}\right)$ & 0.3861 & square mile $\left(\mathrm{mi}^{2}\right)$ \\
\hline \multicolumn{3}{|c|}{ Volume } \\
\hline liter (L) & 33.82 & ounce, fluid (fl. oz) \\
\hline liter (L) & 0.2642 & gallon (gal) \\
\hline liter (L) & 61.02 & cubic inch (in $\left.{ }^{3}\right)$ \\
\hline cubic foot $\left(\mathrm{ft}^{3}\right)$ & 0.02832 & cubic meter $\left(\mathrm{m}^{3}\right)$ \\
\hline \multicolumn{3}{|c|}{ Flow rate } \\
\hline cubic foot per second $\left(\mathrm{ft}^{3} / \mathrm{s}\right)$ & 0.02832 & cubic meter per second $\left(\mathrm{m}^{3} / \mathrm{s}\right)$ \\
\hline cubic meter per second $\left(\mathrm{m}^{3} / \mathrm{s}\right)$ & 70.07 & acre-foot per day (acre-ft/d) \\
\hline cubic meter per second $\left(\mathrm{m}^{3} / \mathrm{s}\right)$ & 22.83 & $\begin{array}{l}\text { million gallons per day } \\
\text { (Mgal/d) }\end{array}$ \\
\hline millimeter per year (mm/yr) & 0.03937 & inch per year (in/yr) \\
\hline \multicolumn{3}{|c|}{ Mass } \\
\hline gram (g) & 0.03527 & ounce, avoirdupois (oz) \\
\hline kilogram (kg) & 2.205 & pound avoirdupois (lb) \\
\hline \multicolumn{3}{|c|}{ Yield Rate } \\
\hline $\begin{array}{l}\text { kilogram per year per square } \\
\text { kilometer }\left(\mathrm{kg} / \mathrm{yr} / \mathrm{km}^{2}\right)\end{array}$ & 350.4 & $\begin{array}{l}\text { ton per year per square mile } \\
\left(\mathrm{tn} / \mathrm{yr} / \mathrm{mi}^{2}\right)\end{array}$ \\
\hline
\end{tabular}

Temperature in degrees Celsius $\left({ }^{\circ} \mathrm{C}\right)$ may be converted to degrees Fahrenheit $\left({ }^{\circ} \mathrm{F}\right)$ as follows:

${ }^{\circ} \mathrm{F}=\left(1.8 \times{ }^{\circ} \mathrm{C}\right)+32$

Specific conductance is given in microsiemens per centimeter at 25 degrees Celsius $\left(\mu \mathrm{S} / \mathrm{cm}\right.$ at $\left.25^{\circ} \mathrm{C}\right)$.

Concentrations of chemical constituents in water are given either in milligrams per liter ( $\mathrm{mg} / \mathrm{L}$ ) or micrograms per liter $(\mu \mathrm{g} / \mathrm{L})$.

Concentrations of $E$. colibacteria are given in most probable number (MPN) of viable colony forming units per 100 milliliters

$(\mathrm{mL})$.

Units of turbidity are given in formazin turbidity units (FNU), which are nephelometric turbidity units based on a formazin standard.

Water year is the 12-month period starting 0 ctober 1 of the previous year, and ending September 30 of the water year. 


\title{
Water Quality in the Anacostia River, Maryland and Rock Creek, Washington, D.C.: Continuous and Discrete Monitoring with Simulations to Estimate Concentrations and Yields of Nutrients, Suspended Sediment, and Bacteria
}

\author{
By Cherie V. Miller, Jeffrey G. Chanat, and Joseph M. Bell
}

\begin{abstract}
Concentrations and loading estimates for nutrients, suspended sediment, and E.coli bacteria were summarized for three water-quality monitoring stations on the Anacostia River in Maryland and one station on Rock Creek in Washington, D.C. Both streams are tributaries to the Potomac River in the Washington, D.C. metropolitan area and contribute to the Chesapeake Bay estuary. Two stations on the Anacostia River, Northeast Branch at Riverdale, Maryland and Northwest Branch near Hyattsville, Maryland, have been monitored for water quality during the study period from 2003 to 2011 and are located near the shift from nontidal to tidal conditions near Bladensburg, Maryland. A station on Paint Branch is nested above the station on the Northeast Branch Anacostia River, and has slightly less developed land cover than the Northeast and Northwest Branch stations. The Rock Creek station is located in Rock Creek Park, but the land cover in the watershed surrounding the park is urbanized.

Stepwise log-linear regression models were developed to estimate the concentrations of suspended sediment, total nitrogen, total phosphorus, and E. coli bacteria from continuous field monitors. Turbidity was the strongest predictor variable for all water-quality parameters. For bacteria, water temperature improved the models enough to be included as a second predictor variable due to the strong dependence of stream metabolism on temperature. Coefficients of determination $\left(\mathrm{R}^{2}\right)$ for the models were highest for log concentrations of suspended sediment (0.9) and total phosphorus (0.8 to 0.9$)$, followed by E. coli bacteria ( 0.75 to 0.8 ), and total nitrogen (0.6).

Water-quality data provided baselines for conditions prior to accelerated implementation of multiple stormwater controls in the watersheds. Counties are currently in the process of enhancing stormwater controls in both watersheds. Annual yields were estimated for suspended sediment, total nitrogen, total phosphorus, and $E$. coli bacteria using the U.S. Geological Survey model LOADEST with hourly time steps of turbidity, flow, and time. Yields of all four parameters were within ranges found in other urbanized watersheds in Chesapeake Bay. Annual yields for all four watersheds over the period of study were estimated for suspended sediment (65,500 166,000 kilograms per year per square kilometer; $\left.\mathrm{kg} / \mathrm{yr} / \mathrm{km}^{2}\right)$, total nitrogen (465 - $\left.911 \mathrm{~kg} / \mathrm{yr} / \mathrm{km}^{2}\right)$, total phosphorus (36 - $\left.113 \mathrm{~kg} / \mathrm{yr} / \mathrm{km}^{2}\right)$, and E. coli bacteria $\left(6.0-38 \times 10^{12}\right.$ colony forming units $\left./ \mathrm{yr} / \mathrm{km}^{2}\right)$. The length of record was not sufficient to determine trends for any of the water-quality parameters; within confidence intervals of the models, results were similar to loads determined by previous studies for the Northeast and Northwest Branch stations of the Anacostia River.
\end{abstract}

\section{Introduction}

The Anacostia River and Rock Creek are two heavily urbanized tributaries to the Potomac River and the Chesapeake Bay. The lower parts of both streams are within Washington, D.C., and the headwaters are in Maryland. The chemical and physical stressors of urban development affect the biological integrity of these tributaries and have led to degraded habitat for aquatic organisms as well as some threats to human health; segments of both rivers are listed as impaired in Maryland's 305b report and selected fish-consumption advisories 
are in effect (Maryland Department of the Environment, 2012). Urban sources of chemical and bacterial contamination include leaking sewer infrastructure, outfalls from industry and sewage-treatment plants, landfills, storm runoff from lawns, gardens, and paved surfaces, and atmospheric deposition. Typically, development around urban streams includes modifications to stream geomorphology such as cement channels, buried segments encased in pipes, decreased or absent riparian buffers, and rechannelization that reduces sinuosity. Modifications to stream channels combined with increases in impervious surfaces in the watershed cause storm discharges to be flashy with higher peak discharges and less infiltration to groundwater, thus enhancing downstream fluxes of contaminants.

With the signing of the Chesapeake Bay Agreement in 1983, all of the states in the bay watershed pledged to work together to study and improve pollution problems in the bay. Signatories to this agreement included Maryland, Pennsylvania, Virginia, Washington, D.C., and the U.S. Environmental Protection Agency (USEPA), which became the Chesapeake Executive Council. In 1987, a new agreement was signed that quantified goals for reductions in nitrogen and phosphorus, and focused research upstream into the watersheds. In 2000, a more comprehensive agreement (Chesapeake 2000) was signed by all of the watershed states and the District of Columbia, with more detailed goals for pollution reduction, habitat restoration, protection of living resources, and public engagement. Due to the slow pace in documented water-quality improvements, in 2010, the USEPA established Total Maximum Daily Loads (TMDLs) for nitrogen, phosphorus, and sediment for the entire bay (U.S. Environmental Protection Agency, 2010). The TMDLs for the bay include 98 impaired stream segments that will be addressed by Watershed Implementation Plans (WIPs) based on maximum allowable loads from all of the sources within the stream segment and developed by each state. Within the State of Maryland, local jurisdictions were provided countywide nutrient-reduction targets and these were used in the development of county-specific WIPs for tracking pollutant reductions toward the target goals (U.S. Environmental Protection Agency, 2010).

Both the Anacostia River and Rock Creek are listed in Maryland's 303(d) report (Maryland Department of the Environment, 2012) as being impaired for biological integrity, nutrients, sediment, and bacteria, as well as some segments specifically listed for certain organic compounds. The District of Columbia and the State of Maryland have developed local TMDLs as goals for limiting the amount of substances that impair these water bodies. The District of Columbia, the State of Maryland, and local jurisdictions are working to improve both tributaries with stormwater retrofits and stream-restoration programs that address sources of contaminants as well as reductions in runoff volume (Montgomery County Department of Environmental Protection, 2012a,b). The Municipal Separate Storm Sewer System (MS4) permits require local jurisdictions to document current conditions and progress towards TMDL goals over time. Water-quality data for nutrients, suspended sediment, and bacteria have been collected on Rock Creek and the Anacostia River at multiple locations over the last several decades and more intensively over the last decade to address these needs. Data have provided baselines for conditions prior to accelerated implementation of multiple stormwater controls in the watersheds. Montgomery and Prince George's Counties have been adding stormwater retrofits in the Anacostia River watershed since the late 1990s. The results in the current study help to address some of the data and modeling needs for tracking progress for the Maryland WIPs and towards meeting MS4 permit requirements.

\section{Purpose and Scope}

The purpose of this report is to summarize water-quality data collected during water years 2005 through 2011 (each water year begins on October 1 of the previous calendar year and ends on the following September 30) from the Anacostia River in Maryland and Rock Creek in Washington, D.C. There are some gaps in the datasets due to discontinued record. Water-quality data included concentrations of nutrients, suspended sediment, and E. coli bacteria, as well as continuous monitoring for physical parameters, water temperature, specific conductance, $\mathrm{pH}$, concentration of dissolved oxygen and turbidity, at each station. Loads and yields, estimated from water-quality data, also are presented. Estimates of loads will be used by the Montgomery County Department of Environmental Protection and the State of Maryland to satisfy MS4 permits, and to track progress towards achieving TMDLs for impacted stream segments. 
The report summarizes water-quality monitoring data collected at four stations: Northeast Branch Anacostia River at Riverdale, Maryland (USGS station 01649500), Northwest Branch Anacostia River near Hyattsville, Maryland (USGS station 01651000), Paint Branch near College Park, Maryland (USGS station 01649190), and Rock Creek at Joyce Road, Washington, D.C. (USGS station 01648010). Summaries include discrete and continuous water-quality data, regression models that relate concentrations and instantaneous loads of total nitrogen (TN), total phosphorus (TP), suspended sediment (SS), and E. coli bacteria to continuous physical parameters measured by a multiparameter datasonde, and annual loads for TN, TP, SS, and E. coli.

\section{Description of the Study Area}

The Anacostia River and Rock Creek are adjacent tributaries to the tidal Potomac River. The headwaters of Rock Creek are in Montgomery County, Maryland and the headwaters of the Anacostia River are in Montgomery and Prince George's Counties, Maryland; the lower, oligohaline tidal parts of both streams are in or near Washington, D.C. (fig. 1). The Northeast Branch Anacostia River at Riverdale, Maryland and the Northwest Branch Anacostia River near Hyattsville, Maryland monitoring stations are both near the major confluence of the Anacostia River at Bladensburg, Maryland. This is approximately at the Fall Line, a physiographic feature in the Mid-Atlantic region that defines the boundary between the Piedmont and Coastal Plain Physiographic Provinces and generally marks a shift in slope and transition to tidal influence. Flow at these two stations has been monitored by USGS since 1938. Water-quality data for nutrients, organic compounds, SS, bacteria, trace metals, and continuous physical parameters have been collected and measured intermittently by USGS at these two stations since 2003. Measurements of water quality by USGS were discontinued at Northwest Branch in June 2010, and are now collected by the Maryland Department of Natural Resources as part of their CORE and TRENDS network. Load estimates for nutrients, trace metals, and SS for calendar years 2004 and 2005 for the Northeast and Northwest Branches of the Anacostia River were published in an earlier USGS report (Miller, Gutiérrez-Magness, and others, 2007).

Paint Branch near College Park, Maryland (USGS station 01649190) is nested in the upper watershed of the Northeast Branch of the Anacostia River at the boundary between Montgomery and Prince George's Counties. The Paint Branch watershed has similar but slightly less urban land cover compared to the Northeast Branch watershed (table 1). Flow, discrete samples for nutrients, SS, and bacteria, and continuous water quality have been monitored by USGS at the Paint Branch station since October 2007 and are reported herein through September 2011. One important influence on the Paint Branch watershed over the study period has been the development of an 18-mile-long major highway, the Intercounty Connector (ICC), which was begun in 2007 and just recently opened in 2011 (fig. 1). The ICC cuts through the forested upper watersheds of the Anacostia River and Rock Creek, and the Maryland State Highway Administration has invested in a fairly extensive environmental program to mitigate negative environmental impacts during and after construction. These include a Special Protection Area (SPA) in the upper watershed where development projects since the mid 1990s have required enhanced environmental review and additional stormwater management to protect high-quality stream resources. Throughout the Anacostia River watershed, other restoration projects also are planned or being completed (U.S. Army Corps of Engineers, 2010).

The monitoring station Rock Creek at Joyce Road (USGS station 01648010) was established in December 2006 for the collection of water-quality data. Flow had been measured approximately 2 kilometers $(\mathrm{km})$ upstream at Rock Creek at Sherrill Drive (USGS station 01648000) since 1929, and discharge measurements from the Sherrill Drive station were used in conjunction with water-quality data from the Joyce Road station for loading calculations. A small tributary and a storm outfall from $16^{\text {th }}$ Street in the District of Columbia enter Rock Creek between these stations and have a small effect on discharge at the Joyce Road station that is discussed in more detail in the next section.

Historical evaluations of water quality in the Anacostia River and Rock Creek have been documented in other USGS studies that provide more detailed watershed descriptions (Anderson and others, 2002; Miller, Weyers, and others, 2006; Miller, Gutiérrez-Magness, and others, 2007; Phelan and Miller, 2010). The periods of record for water-quality data varied among the stations and are subject to several gaps in data (table 2). 


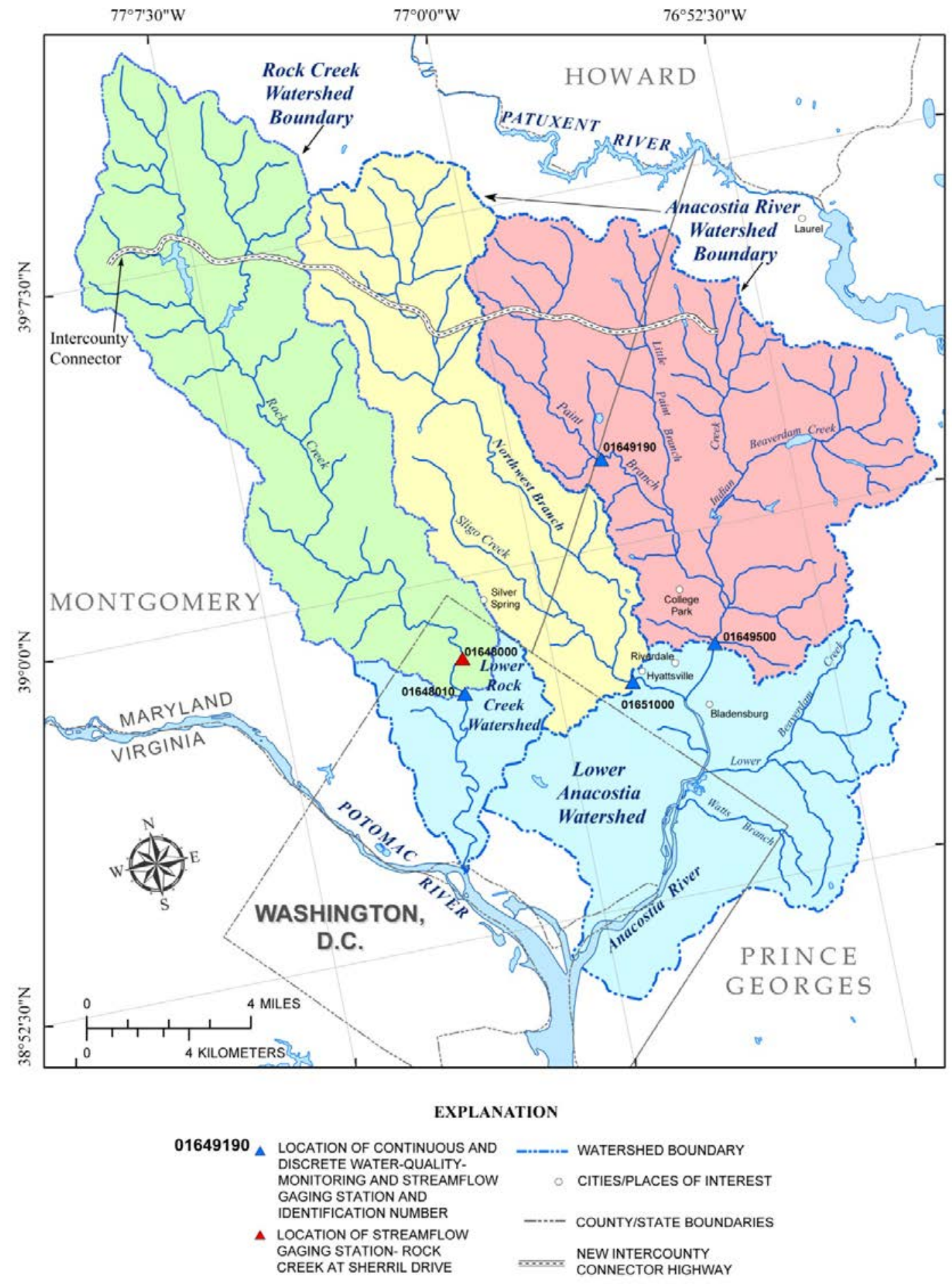

Figure 1. Locations of the Anacostia River and Rock Creek watersheds and U.S. Geological Survey monitoring stations used in this study [Northeast Branch Anacostia River at Riverdale, Maryland (01649500), Northwest Branch Anacostia River near Hyattsville, Maryland (01651000), Paint Branch near College Park, Maryland (01649190), Rock Creek at Joyce Road, Washington, D.C. (01648010) and Rock Creek at Sherrill Drive, Washington, D.C. (01648000)]. 
Table 1. Percentages of land cover in the watersheds above U.S. Geological Survey monitoring stations: Northeast Branch Anacostia River at Riverdale, Maryland (01649500); Northwest Branch Anacostia River near Hyattsville, Maryland (01651000); Paint Branch near College Park, Maryland (01649190); and Rock Creek at Joyce Road, Washington, D.C. (01648010).

[Data are from the National Land Cover Database (NLCD) 2006 (Fry and others, 2011). Categories are grouped so that urban/suburban contains all developed land cover, agriculture contains pasture/hay and row crops, forested/undeveloped land cover includes forests and mixed shrublands, and wetlands include woody and emergent herbaceous wetlands; USGS, U.S. Geological Survey; \%, percent; percentages may not total 100 due to rounding and minor categories that were not included]

\begin{tabular}{ccccc}
$\begin{array}{c}\text { USGS station } \\
\text { number }\end{array}$ & $\begin{array}{c}\text { Urban/ } \\
\text { Suburban } \\
\mathbf{\%}\end{array}$ & $\begin{array}{c}\text { Agriculture } \\
\mathbf{\%}\end{array}$ & $\begin{array}{c}\text { Forested/ } \\
\text { Undeveloped } \\
\mathbf{\%}\end{array}$ & $\begin{array}{c}\text { Wetlands } \\
\mathbf{\%}\end{array}$ \\
\hline 01649190 & 57 & 7.1 & 33 & 2.1 \\
01649500 & 63 & 5.6 & 26 & 4.8 \\
01651000 & 66 & 7.6 & 24 & 1.5 \\
01648010 & 67 & 7.2 & 23.8 & 1.6 \\
\hline
\end{tabular}

Table 2. Periods of record for discharge and water-quality data that are summarized in this report for Northeast Branch Anacostia River at Riverdale, Maryland (01649500), Northwest Branch Anacostia River near Hyattsville, Maryland (01651000), Paint Branch near College Park, Maryland (01649190), Rock Creek at Joyce Road, Washington, D.C. (01648010, water quality only), and Rock Creek at Sherrill Drive, Washington, D.C. (01648000, flow only).

[USGS, U.S. Geological Survey; km², square kilometers; --, not collected]

\begin{tabular}{|c|c|c|c|c|}
\hline $\begin{array}{c}\text { USGS station } \\
\text { number }\end{array}$ & $\begin{array}{c}\text { Basin } \\
\text { area } \\
\left(\mathbf{k m}^{2}\right) \\
\end{array}$ & Discharge & $\begin{array}{c}\text { Discrete } \\
\text { water-quality } \\
\text { data } \\
\end{array}$ & $\begin{array}{c}\text { Continuous } \\
\text { water-quality } \\
\text { data } \\
\end{array}$ \\
\hline 01649190 & 34 & 2007 - present & Jul/2007 - Sep/2011 & Oct/2007 - Sep/2011 \\
\hline 01649500 & 189 & 1938 - present & $\begin{array}{c}\mathrm{Jul} / 2003-\mathrm{Dec} / 2005 \\
\mathrm{Jul} / 2006-\mathrm{Jun} / 2007 \\
\mathrm{Mar} / 2008-\mathrm{Sep} / 2011\end{array}$ & $\begin{array}{c}\text { Dec/2003 - Dec/2005 } \\
\text { Jul/2006 - Nov/2007 } \\
\text { Mar/2008 - Sep/2011 }\end{array}$ \\
\hline 01651000 & 128 & 1938 - present & $\begin{array}{c}\mathrm{Jul} / 2003-\mathrm{Dec} / 2005 \\
\mathrm{Jul} / 2006-\mathrm{Jun} / 2007 \\
\mathrm{Mar} / 2008-\mathrm{Jun} / 2010\end{array}$ & $\begin{array}{c}\text { Feb/2004 - Dec/2005 } \\
\text { Sep/2006 - Nov/2007 } \\
\text { Feb/2008 - Jun/2010 }\end{array}$ \\
\hline 01648010 & 165 & -- & Dec/2006 - Sep/2011 & -- \\
\hline 01648000 & 161 & 1929 - present & -- & - - \\
\hline
\end{tabular}




\section{Methods}

Two basic types of water-quality and -quantity data were collected at the sampling stations on the Northeast and Northwest Branches of the Anacostia River and at Paint Branch: (1) continuous measurements with a pressure transducer for gage height (converted to stream discharge), and a multiparameter datasonde for water temperature, specific conductance, $\mathrm{pH}$, concentration of dissolved oxygen, and turbidity; and (2) discrete measurements for concentrations of nutrients, SS, and bacteria. On Rock Creek, only discrete samples were collected during the period of record for this study. All data are archived in the USGS National WaterInformation System (NWIS) database and are available upon request from the USGS Maryland-Delaware-D.C. Water Science Center (MD-DE-DC WSC) in Baltimore, Maryland.

Field methods described in this report are documented in the USGS National Field Manual (NFM) for the collection of water-quality data (U.S. Geological Survey, variously dated) and Guidelines and Standard Procedures for Continuous-Water-Quality Monitors (Wagner and others, 2006). Chapters of the NFM are updated on a continuous basis and are available online at http://water.usgs.gov/owq/FieldManual/index.html.

\section{Measurements of Stream Discharge and Continuous Water Quality}

Discharge was estimated from river stage (gage height) that had been historically recorded at each of the stations using a stilling well and float recorder, but more recently by use of a pressure transducer. The gage height was recorded every 15 minutes, individual measurements of flow were made throughout the range of stages, and a stage-discharge relation was maintained to create a continuous record of flow. The gaging stations at both the Northeast and Northwest Branches of the Anacostia River have operated almost continuously from 1938 to the present. The station at Paint Branch was started in 2007. Discharge for Rock Creek was monitored upstream at the Sherrill Drive station and a rating curve was developed to document differences in discharge measurements under multiple flow conditions between the Joyce Road and Sherrill Drive stations. Rating curves between Sherrill Drive and Joyce Road quantified an 11-percent difference in discharge during base-flow and low-flow conditions (21 cubic feet per second $\left(\mathrm{ft}^{3} / \mathrm{s}\right)$ or less). Bank-full and stormflows differed less between sites with, for example, a 7-percent difference observed at $32 \mathrm{ft}^{3} / \mathrm{s}$, a 3.5-percent difference observed at $70 \mathrm{ft}^{3} / \mathrm{s}$, and less than a 1-percent difference observed during a stormflow of $1,905 \mathrm{ft}^{3} / \mathrm{s}$. Mean-daily discharges below $21 \mathrm{ft}^{3} / \mathrm{s}$ occurred 25 percent of the time from 2007 to the present; however, the majority of flow volume and contaminant loadings occurred during storm events when differences between the sites were smaller. Of the water-quality samples collected at Joyce Road, 9 percent were collected within the low-flow regime. Discharge at Sherrill Drive was used for modeling in this report, without further modification from the rating between the two stations.

Continuous data for water temperature, specific conductance, $\mathrm{pH}$, concentration of dissolved oxygen, and turbidity were collected using YSI models 6600 or 6920V2 multiparameter datasondes deployed in the rivers and configured to record each parameter every 15 minutes. Observations were transmitted to an electronic Campbell Scientific CR10X data logger, that uploaded data every 4 hours to satellite and then to a USGS server at the USGS MD-DE-DC WSC. Continuous data are reported in near-real time online at http://waterdata.usgs.gov/md/nwis/current/?type=quality.

Data accuracy and precision were maintained by inspecting and calibrating equipment at intervals ranging from 1 to 6 weeks. Hydrologic conditions, data quality (fouling and drift), and the known functional limitations of the equipment dictated servicing frequency. Multiple observations of each parameter were made during site visits to determine separate corrections for fouling and instrument drift. Standards for specific conductance were prepared and quality-assured at the USGS National Water-Quality Laboratory (NWQL) in Denver, Colorado. Standards for $\mathrm{pH}$ were purchased from the Fisher Scientific Company. Formazin-based standards for turbidity were manufactured by GFS Chemicals (AMCO Clear) and were used without dilution. When calibrations exceeded acceptable criteria as defined by Wagner and others (2006), shifts and corrections were applied to the continuous-data records in the USGS NWIS database after each completed field inspection; data that did not meet quality criteria were either flagged with a rating of lower quality or deleted from the final 
record (Wagner and others, 2006). Corrected (provisional data) were displayed in near-real time on the USGS web page of the MD-DE-DC WSC. After review, final approved data were published in the USGS Annual WaterData Report series for water years during which data were collected. USGS Annual Data Reports are available online at $h t t p: / / w d r . w a t e r . u s g s . g o v$.

\section{Collection of Discrete Water-Quality Samples}

Discrete samples for water quality were collected at a fixed monthly frequency, using equal-width increment (EWI) sampling techniques and an isokinetic sampler for vertical integration when flow velocity was greater than $1.5 \mathrm{ft}^{3} / \mathrm{s}$ or a weighted-bottle sampler for slower flows (U.S. Geological Survey, variously dated). Each discrete sample had associated in-stream water temperature, $\mathrm{pH}$, specific conductance, dissolved oxygen, and turbidity recorded from a handheld YSI field meter (model 6600 or 6920V2). Multiple depth-integrated subsamples were collected at equal intervals across the stream (approximately 10 sections) and composited into an acid-washed polyethylene churn splitter to collect a representative flow-weighted sample of the entire stream (fig. 2A). Samples for bacteria were collected from the center of flow or in the automatic sampler into a sterile polyethylene bottle and stored chilled. The samples were processed within the housing at the monitoring station, in a clean USGS field van, or at the USGS MD-DE-DC WSC laboratory to avoid environmental contamination (fig. 2B). Subsamples of whole water for nutrients and SS were dispensed first into clean polyethylene bottles, while churning at a constant prescribed rate. Samples for dissolved analysis were then collected from the churn splitter using a peristaltic pump with an in-line polycarbonate capsule filter [0.45 $\mu \mathrm{m}$ (micrometer) effective pore size]. During base flow, the cross section was waded for sampling, and during storm events, EWI samples were collected from a bridge using a USGS DH-95 isokinetic sampler (fig. 2C) or with an automatic sampler with a single-point intake on the side of the stream. Samples for whole-water analysis of nutrients were preserved with 1 milliliter (mL) of sulfuric acid. Samples for nutrients were chilled to less than $4^{\circ} \mathrm{C}$ (degrees Celsius) and shipped on ice overnight to the USGS NWQL in Denver, Colorado. Samples for SS were stored in a cool dark location prior to being shipped within 1 to 2 months to the USGS Sediment Laboratory in Louisville, Kentucky. 

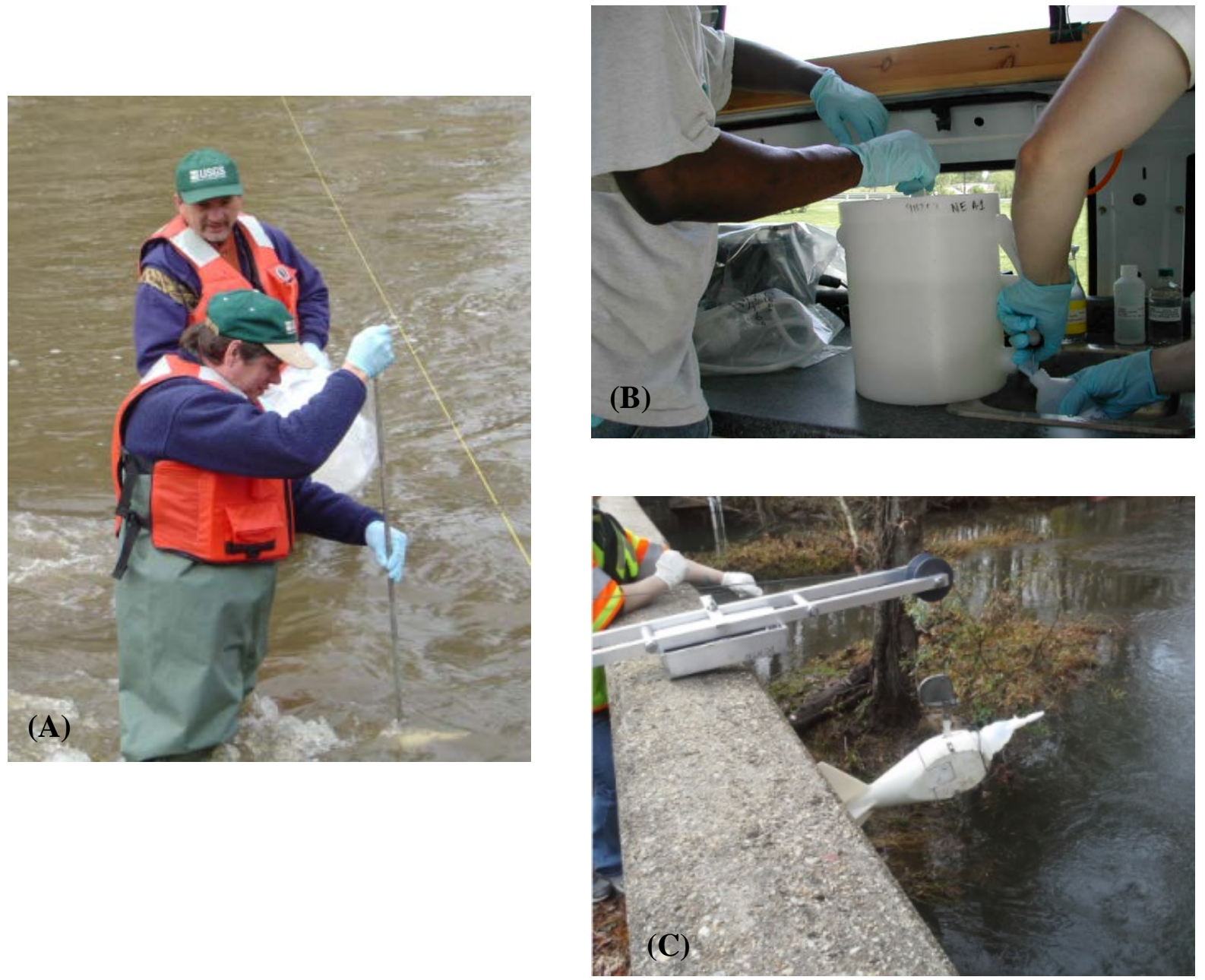

Figure 2. Collection of water-quality samples using equal-width-increment (EWI) sampling: (A) collecting depthintegrated subsamples at equal-width intervals across the stream cross section; (B) compositing and collecting subsamples from a churn splitter in a clean van; and (C) collecting an integrated EWI sample with a DH-95 sampling device from a bridge. (Photographs by U.S. Geological Survey) 
An automatic sampler was installed at each station to facilitate sampling during storm events (fig. 3A). Automatic samplers initiated when pressure transducers returned a stage value that exceeded a preset threshold or they were manually triggered remotely. For each sample, four 1-liter bottles were collected: a pre-tared bottle that was capped and stored for sediment without further subsampling, two bottles for processing nutrient samples, and a pre-sterilized bottle for bacteria. After a storm, the hydrograph was examined and three to four sets of the timediscrete samples were selected to capture the rise, peak, and falling limbs of the storm. To compare results for EWI and automatic sampler methods, quality-control samples were collected simultaneously using both techniques over a range of hydrologic conditions.
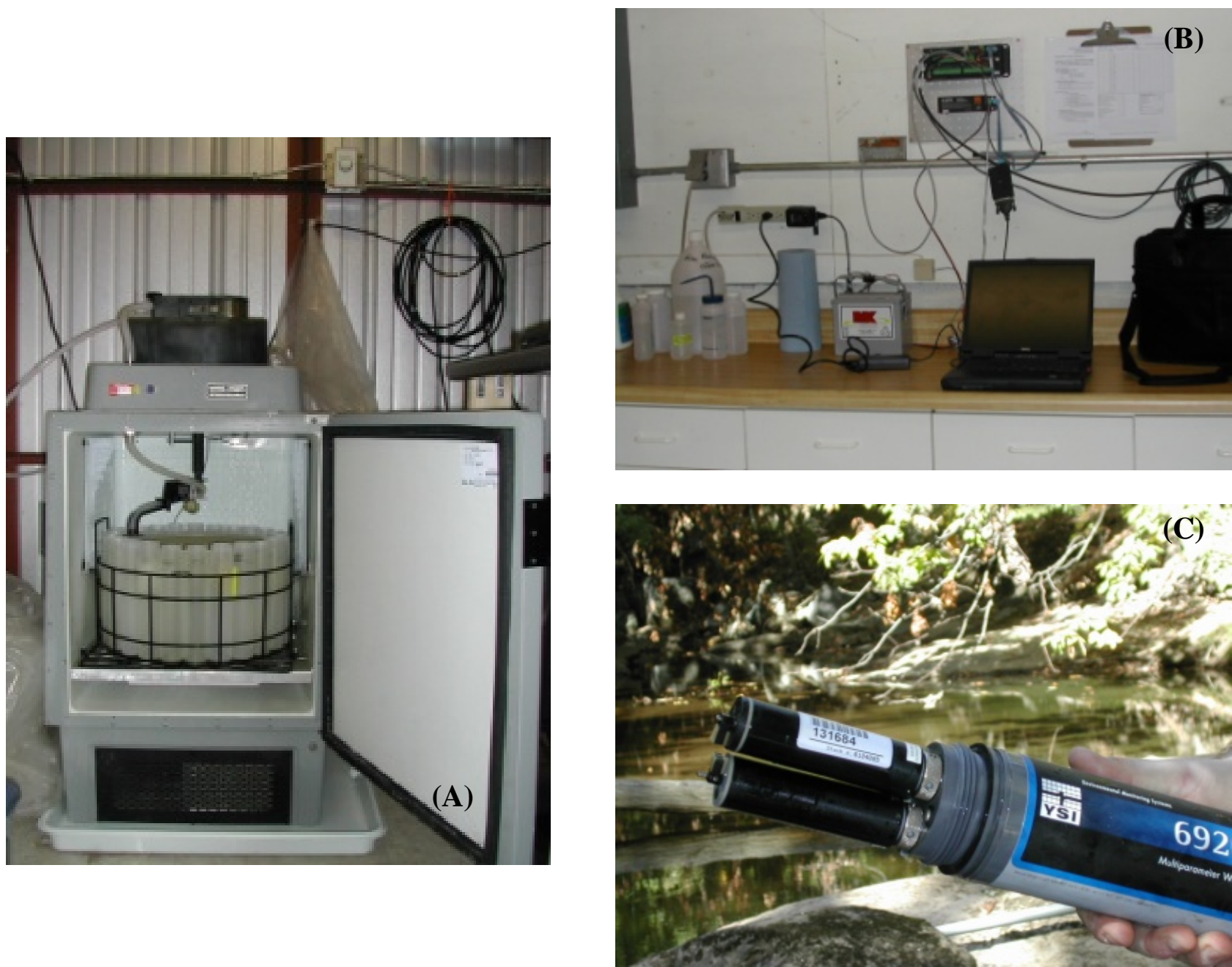

Figure 3. (A) Automatic sampler with (B) data logger. The data logger records physical parameters from (C) a datasonde deployed in the stream, uploads data via satellite to the worldwide web, and triggers the automatic sampler at a selected gage height to collect water-quality samples over a storm hydrograph. (Photographs by U.S. Geological Survey) 

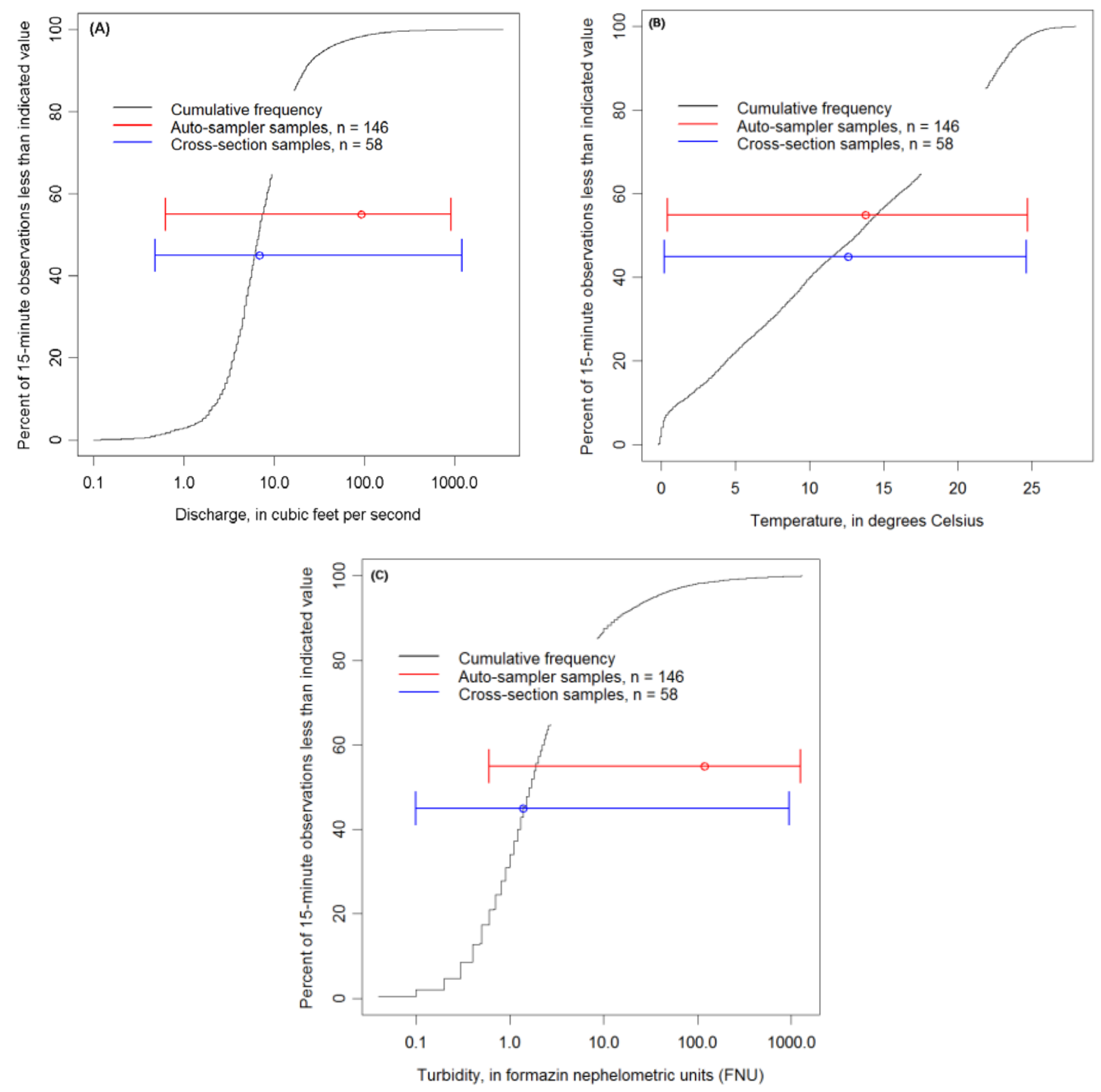

Figure 4. Duration curves for (A) discharge, (B) water temperature, and (C) turbidity at Paint Branch near College Park, Maryland (USGS station 01649190) over the period of study. The ranges of flow conditions over which equal-width-increment (EWI) and automatic-sampler samples were collected are plotted on the duration curves.

Duration curves of discharge, water temperature, and turbidity measured over the study period at Paint Branch with an overlay of the ranges of flows where water-quality samples were collected, demonstrate that measurements of water quality covered full ranges of hydrologic conditions (figs. 4A-C). Duration curves for the other three stations are not shown here, but are similar. 


\section{Laboratory Methods}

For the Northeast and Northwest Branches of the Anacostia, all nutrient samples were analyzed at the USGS NWQL in Denver, Colorado, samples for SS were analyzed at the USGS Sediment Laboratory in Louisville, Kentucky, and samples for bacteria were analyzed at the MD-DE-DC WSC. For the stations on Paint Branch and Rock Creek, from July 2007 through February 1, 2008, samples for nutrients and E. coli were analyzed at the Washington Suburban Sanitary Commission (WSSC) laboratory in Laurel, Maryland. Since February 11, 2008, all water-quality samples collected at Paint Branch and Rock Creek have been analyzed by USGS laboratories.

Samples for total and soluble forms of phosphorus and Kjeldahl nitrogen were digested concurrently in block digestors at high temperature with a mercury (HgII) catalyst. Ammonium ions (including both those originally present and those generated by the procedure) were analyzed colorimetrically by a salicylatehypochlorite Berthelot-reaction procedure using an air-segmented continuous-flow analyzer. Ammonia nitrogen was analyzed separately by the same colorimetric procedure. Phosphorus was analyzed in a separate aliquot from the same digestate using the ammonium-molybdate colorimetric method and automated segmented flow (Fishman, 1993; Patton and Truitt, 2000). Nitrite-nitrogen was analyzed by diazotization and colorimetric detection in automated segmented flow. Nitrate was reduced by cadmium metal and analyzed as nitrite to give total nitrate/nitrite-nitrogen (Fishman, 1993). Nitrate-nitrogen was determined by difference. TN was calculated as the sum of total Kjeldahl nitrogen and total nitrate/nitrite nitrogen. All methods at the USGS NWQL are quality-assured by the National Environmental Laboratory Accreditation Program (NELAP), the USGS Branch of Quality Systems that conducts blind audits, and the USGS Standard Reference Sample (SRS) Program.

Concentrations of SS and the percent of sediment finer than $0.63 \mu \mathrm{m}$ were analyzed using filtration and gravimetric methods at the USGS Sediment Laboratory in Louisville, Kentucky. All methods and qualityassurance procedures for sediment analyses are documented in the quality-assurance plan for the USGS Sediment Laboratory in Louisville, Kentucky (Shreve and Downs, 2005).

E. coli bacteria were enumerated using the Colilert method. In essence, $100 \mathrm{~mL}$ of sample collected in a sterile bottle was combined with a prepackaged dry-enzyme media, transferred to sterile Quanti-Trays (IDEXX) with counting wells, and incubated for 24 or 18 hours ( $+/-1$ hour) at $35^{\circ} \mathrm{C}\left(+/-1^{\circ}\right)$. Wells that were positive for total coliform (nutrient indicator turned yellow) and for E. coli (nutrient indicator fluoresced under blacklight) were counted and statistically converted to Most Probable Number (MPN) of viable colony-forming units per 100 $\mathrm{mL}$ of sample. Initially Colilert-24 was used, which has a 24-hour incubation period, but beginning in August 2008, the method was changed from 24- to 18-hour incubation periods using the Colilert-18 media. For storm events, where bacterial concentrations were normally higher than those for base flow, samples were diluted to $10 \mathrm{X}$ or $100 \mathrm{X}$ with sterile water to accurately quantify the bacteria. Multiple dilutions were used to bracket the expected concentrations for each sample, and the lowest dilution that could be enumerated was recorded for the result. Colilert and traditional multi-tube fermentation or membrane filtration methods have been shown to be very comparable, but the Colilert method is more sensitive, particularly when concentrations of bacteria are low (Eckner, 1998).

\section{Evaluation of Data Integrity}

From 2008 through 2011, a total of 55 field and automatic-sampler blanks were collected among the four sampling stations and analyzed for nutrients, SS, and (or) bacteria. Field blanks were collected by processing inorganic-free blank water for nutrients and suspended sediment, and sterile water for bacteria through the entire collection process including the bottle sampler, churn splitter, and capsule filter. To evaluate potential bias with autosampling, intake lines were raised out of the river, flushed with deionized water, and then used to pass inorganic-free blank water through the intake system and the entire sample-processing procedures. Concentrations were found to be below reporting limits or not detected for most water-quality constituents. On occasion, measurable concentrations indicating contamination were observed but usually at a level near or below 
reporting thresholds. Significant contamination (when blank values were greater than 10 percent of environmental values) was observed in a field blank for SS collected on October 14, 2009 and reported as 47 milligrams per liter (mg/L). All other constituents in this blank sample were below their reporting limits. It was determined that this was an anomalous result of an improperly cleaned sediment-sample bottle, and that this occurrence was not typical of other samples. Additionally, approximately 55 percent of field and automaticsampler blanks had concentrations of ammonia that exceeded 10 percent of the environmental sample values. Topical blanks on equipment and processes did not return detections of ammonia above the $0.01 \mathrm{mg} / \mathrm{L}$ reporting threshold, indicating that ambient contamination at sampling locations is a probable source of low-level ammonia contamination. Review of all data for ammonia blanks indicates that samples are subject to background contamination by ammonia at levels close to the reporting limit. Any individual environmental concentrations within the 10-percent range of background blank values are likely to be influenced by low-level background contamination, but for $\mathrm{TN}$, the datasets had minimal bias relative to ambient concentrations and were adequate for load calculations and other data applications. A summary of the results for blank samples (table 3) provides the potential bias for each parameter.

Table 3. Summary of potential bias from all field and automatic-sampler blanks for the $90^{\text {th }}$ percentile of samples.

[The estimated bias for each parameter can be interpreted as, for example for total Kjeldahl nitrogen - in at least 90 percent of the samples the potential contamination is expected to be no greater than 0.11 milligrams per liter (mg/L) with a 96percent degree of confidence; MPN, most probable number of viable colony-forming units per $100 \mathrm{milliliters;} \mathrm{mL,}$ milliliters; \%, percent]

\begin{tabular}{|c|c|c|c|}
\hline Parameter & Reporting limit & $\begin{array}{c}\text { Estimate of potential } \\
\text { positive bias (upper } \\
\text { confidence limit) }\end{array}$ & $\begin{array}{c}\text { Percentage of blanks } \\
\text { below reporting level }\end{array}$ \\
\hline Total Kjeldahl nitrogen & $0.07 \mathrm{mg} / \mathrm{L}$ & $0.11 \mathrm{mg} / \mathrm{L}(96 \%)$ & $73 \%$ \\
\hline Ammonia nitrogen & $0.020 \mathrm{mg} / \mathrm{L}$ & $0.025 \mathrm{mg} / \mathrm{L}(90 \%)$ & $89 \%$ \\
\hline Nitrate/nitrite nitrogen & $0.020 \mathrm{mg} / \mathrm{L}$ & $0.03 \mathrm{mg} / \mathrm{L}(98 \%)$ & $80 \%$ \\
\hline Nitrite nitrogen & $0.0010 \mathrm{mg} / \mathrm{L}$ & $0.001 \mathrm{mg} / \mathrm{L}(98 \%)^{*}$ & $100 \%$ \\
\hline Total phosphorus & $0.01 \mathrm{mg} / \mathrm{L}$ & $0.01 \mathrm{mg} / \mathrm{L}(96 \%)$ & $87 \%$ \\
\hline E. coli & $1 \mathrm{MPN} / 100 \mathrm{~mL}$ & $5 \mathrm{MPN} / 100 \mathrm{~mL}(92 \%)$ & $93 \%$ \\
\hline Suspended sediment & $0.05 \mathrm{mg} / \mathrm{L}$ & $1 \mathrm{mg} / \mathrm{L}(94 \%)$ & $56 \%$ \\
\hline
\end{tabular}

*Estimated, all values were censored below the reporting level.

Water-quality samples for nutrients and bacteria collected from July 2007 to March 2008 were analyzed at the WSSC laboratory in Laurel, Maryland. Samples from the USGS SRS Program and split replicate samples sent to each laboratory were used to investigate variability and significant differences between laboratory results for nutrients from the WSSC laboratory and NWQL. For example, in the spring and fall of 2007, independent standard reference samples were sent to the WSSC laboratory and the NWQL for comparative analysis and lab performance testing. The WSSC laboratory's percent difference from standard ranged from 0 to 74 percent with a significant difference from standard in one of the reported measurements of nitrite + nitrate. NWQL's percent difference from standard ranged from 0 to 7.4 percent with no observed significant differences from standard. Significant differences from standards are defined as greater than +/- 2 standard deviations from the most probable value. Since March 2008, the NWQL has been used for nutrient analysis, and NWQL performance is monitored on a regular basis to ensure data integrity. All methods at NWQL are audited by the NELAP, the USGS Branch of Quality Systems that conducts blind sample audits, and the USGS SRS Program. More information regarding NWQL quality assurance can be found online at http://nwql.usgs.gov/Public/quality.shtml. When the project changed analytical laboratories for nutrients, measurements of bacteria also were also changed 
to the USGS MD-DE-DC WSC to obtain the accuracy and reporting limits that were needed for modeling loads. Multiple replicate samples were collected at that time to compare data from both labs, but relative percent differences (RPDs) were large. Data from both the WSSC laboratory and the NWQL were used for modeling purposes because the model evaluates the errors and provides confidence intervals on the results that include error from data scatter, and because there was enough data from WSSC laboratory to compensate for the loss of precision.

In August 2008, bacterial-testing methods were changed from Colilert-24 to Colilert-18 in order to facilitate analysis; this step reduced the incubation period from 24 to 18 hours. Fifteen sets of replicate samples from study sites were analyzed, and RPDs were computed to determine comparability between these two methods. RPDs ranged from 0 to 30 percent, with 73 percent of the samples showing less than a 15 RPD. Observed variability greater than 15 percent in the USGS laboratory comparisons typically occurred at levels that required sample dilution (1:10 or 1:100), where precision is unavoidably reduced regardless of the method. It was concluded by USGS personnel that a switch from Colilert-24 to Colilert-18 would not diminish data integrity as variability in USGS processed replicates was similar to environmental variability (approximately 10 RPD observed in replicate comparisons), and that datasets derived from the two methods were comparable and could be combined for analysis and interpretation.

USGS has developed very detailed methodologies to collect representative samples from stream cross sections. These methods typically involve analysis of the cross-sectional and vertical variability in flow and segmentation of the cross section into EWI or equal-discharge increments (EDI) that are sampled and composited into a churn splitter (U.S. Geological Survey, variously dated). Conversely, automatic samplers collect point samples that are often not representative of the entire stream cross section, but they provide a distinct advantage for sampling designs as they allow collection of multiple samples over a storm at key points in the hydrographs at times when physically collecting a sample may not be practical or even possible. Therefore, when automatic samplers are used, documentation of representativeness of a true EWI or EDI measurement must be made. Comparisons are often complicated by rapidly changing conditions over a storm event, but nonetheless provide insight on concentration data generated from an automatic sampler. Replicate samples comparing point to crosssectional sampling across different hydrologic conditions and among the four sampling stations had RPDs that were usually less than 10 percent, but TP and SS had recurring large (greater than 10 percent) RPDs at all sites, which makes physical sense as suspended particles are dependent on flow velocities and may be highly variable, both spatially and temporally, in high-flow waters (Horowitz, 1991). Out of a total of 41 replicate pairs for the concentration of TP, 3 exceeded +/- 10-percent difference: Northwest Branch (33 percent on May 27, 2008), Northeast Branch (20 percent on July 19, 2011), and Paint Branch (17 percent on May 26, 2009). RPDs among replicate samples of SS at all four sites frequently exceeded 10 percent and ranged from 0 to 60 percent without an observable bias between the sampling methods. Multiple explanations are possible for observed differences in replicate comparisons of SS including: (1) intake tubing may be overwhelmed by sediment during the storm and not completely purge leading to the collection of an over-biased sediment concentration; (2) large sand-size particles are not as easily pulled up through the sampling lines and may drop out before reaching the automatic sampler; (3) flow conditions are highly variable during storm events, sometimes changing on the order of minutes and comparisons between the automatic sampler and EWI samples are difficult to sync in time; and (4) the system is naturally heterogeneous with random large pieces of materials that may or may not be picked up in a particular sample. When buried intake lines were identified as a problem, related data were deleted from the dataset. The loss of large particles through the intake was unavoidable and was documented by comparisons during high flows. One way to control for temporal variability during sampling was to use a datasonde to more quickly profile field parameters across the stream. An EWI sample takes approximately 30 to 45 minutes to collect and represents an average of the flow over that time period, while a cross section with a datasonde can be accomplished in approximately 10 minutes. Cross sections of specific conductance at all stations varied by less than 5 percent and usually by less than 1 percent. Relative standard deviations for turbidity also were usually less than 5 percent but were more variable than specific conductance with a few occurrences of high variability. For example during a base-flow measurement at Northeast Branch Anacostia River on March 3, 2011, all of the turbidity readings were 6.7 to 9.2 formazin nephelometric units (FNU), except for the left edge of water where there was a visible grey plume and the value was 39 FNU. An example of a storm event with an average 
discharge of 4,610 $\mathrm{ft}^{3} / \mathrm{s}$ at the same station on May 12, 2008 had cross-sectional measurements of turbidity of 240, 201, 260, and $240 \mathrm{FNU}$, with a relative standard deviation of 8.7 percent. In spite of the limitations of point sampling with an automatic sampler, the data still provide very useful information, given the critical need for data collected during the initial first flush of a storm event in an urban stream when many contaminants are first mobilized.

Comparisons of cross-section to automatic-sampler replicate data at Rock Creek showed nonsystematic biasing of concentrations of nutrients and SS. At this station, high energy during storm events mobilized silt and sand-sized particles that may have made up a large fraction of the SS. Additionally, an eddy in the stream sometimes formed just below the bridge at the intake site, causing large grain-size particles to drop out and cover the automatic-sampler intake orifice during sample collection. Biasing due to siltation at the intake resulted in a total of seven samples being excluded from the Rock Creek record during the 4-year study period. The intake has recently been moved further into the stream course to avoid siltation in the future.

Analytical precision of the collection and analytical methods was determined by pooling all pairs of field replicates from the four stations. Replicate pairs were collected over a range of hydrologic conditions and included pair sets from both EWI and automatic sampling. Replicate pairs analyzed by the WSSC lab were included in the summaries, but not replicate comparisons between labs or between sampling techniques. For each replicate pair, the RPD was calculated and the averages of the RPDs for each parameter are presented in table 4. Replication of whole-water samples (total Kjeldahl nitrogen, TN, E. coli, and SS) was more variable than for dissolved parameters, particularly during storm events when there are larger particles and more debris in the turbulent water column.

Table 4. Summary of sampling and analytical precision determined by field replicates.

[\%, percent]

\begin{tabular}{|c|c|c|}
\hline Parameter & $\begin{array}{c}\text { Average relative } \\
\text { percent difference }\end{array}$ & $\begin{array}{c}\text { Number of } \\
\text { replicate pairs }\end{array}$ \\
\hline Total Kjeldahl nitrogen & $9.1 \%$ & 9 \\
\hline Ammonia nitrogen & $1.9 \%$ & 6 \\
\hline Nitrate/nitrite nitrogen & $2.6 \%$ & 10 \\
\hline Nitrite nitrogen & $0.0 \%$ & 5 \\
\hline Total phosphorus & $8.3 \%$ & 6 \\
\hline E. coli & $8.6 \%$ & 28 \\
\hline Suspended sediment & $13.1 \%$ & 10 \\
\hline
\end{tabular}

Data integrity for the water-quality samples collected by USGS at Northeast and Northwest Branches of the Anacostia River was similarly evaluated in Miller, Gutiérrez-Magness, and others (2007). Quality-control data are available from the USGS MD-DE-DC WSC upon request.

\section{Multiple Linear-Regression Models}

A multiple log-linear-regression model was used to develop proxies for the estimation of concentrations of SS, TN, TP, and E. coli from continuous field measurements with a multiparameter datasonde. Previous studies have shown that turbidity, which can be measured relatively inexpensively and at frequent intervals in the field, is an excellent indicator of water-quality conditions and a statistically good predictor of relative concentrations of constituents such as SS and nutrients (Christensen, 2001; Christensen and others, 2000; Rasmussen and others, 2005; Miller, Gutiérrez-Magness, and others, 2007; Jastram and others, 2009; Chanat and 
others, 2013). Following the approach for stepwise model selection described by Helsel and Hirsch (1992), the first step was to review summary statistics for each variable and to test transformations to improve linearity of relations and normality of distributions of the residuals. Models for SS, TN, TP, and E. coli were developed using stepwise regression in the SPlus Statistical Package (version 8.1, TIBCO Corporation, 2008), whereby variables were added iteratively to maximize the best fit of the model with the minimum number of predictive variables. Rather than basing model decisions on coefficients of determination $\left(\mathrm{R}^{2}\right)$, the SPlus algorithm determined the best model using Akaike's Information Criterion (AIC, Helsel and Hirsch, 1992), which created a statistic based on the measure of model error with a negative correction for the number of explanatory variables. This may be more similar to an adjusted $\mathrm{R}^{2}$, which takes into account the degrees of freedom and thus gives less credit to a model with more explanatory variables.

Transformations have the potential for negative bias when the data are transformed from log space back to linear space (Cohn and others, 1989; Cohn and others, 1992; Helsel and Hirsch, 1992). This is primarily an issue with the highest outliers, which when transformed back to linear space, dominate the calculation of smearing corrections. This results in all back-transformed values being slightly over estimated and becomes a more important issue when loads from estimated concentrations are integrated over time and bias accumulates in the estimates. Following the guidelines of Helsel and Hirsch (1992), once each model was selected, smearing corrections as defined in Duan (1983) were applied to correct for this bias.

For the purposes of regression modeling, data for specific conductance were subsetted to remove biased values during winter months; measurements of specific conductance are strongly and consistently skewed high at all sites during periods when road salt is applied. These high values represent true observations but are erroneous for correlation of SC to nutrients, sediment, or bacteria. The cutoff values for specific conductance at each site were selected by visual inspection and confirmed with correspondence to winter events. The example from Paint Branch (fig. 5) shows the data that were removed with a cutoff value of 350 microsiemens per centimeter $(\mu \mathrm{S} / \mathrm{cm})$. Note that these data are plotted on a log scale. For the Northeast and Northwest Branches Anacostia River, the censoring thresholds for SC were 500 and $570 \mu \mathrm{S} / \mathrm{cm}$, respectively.

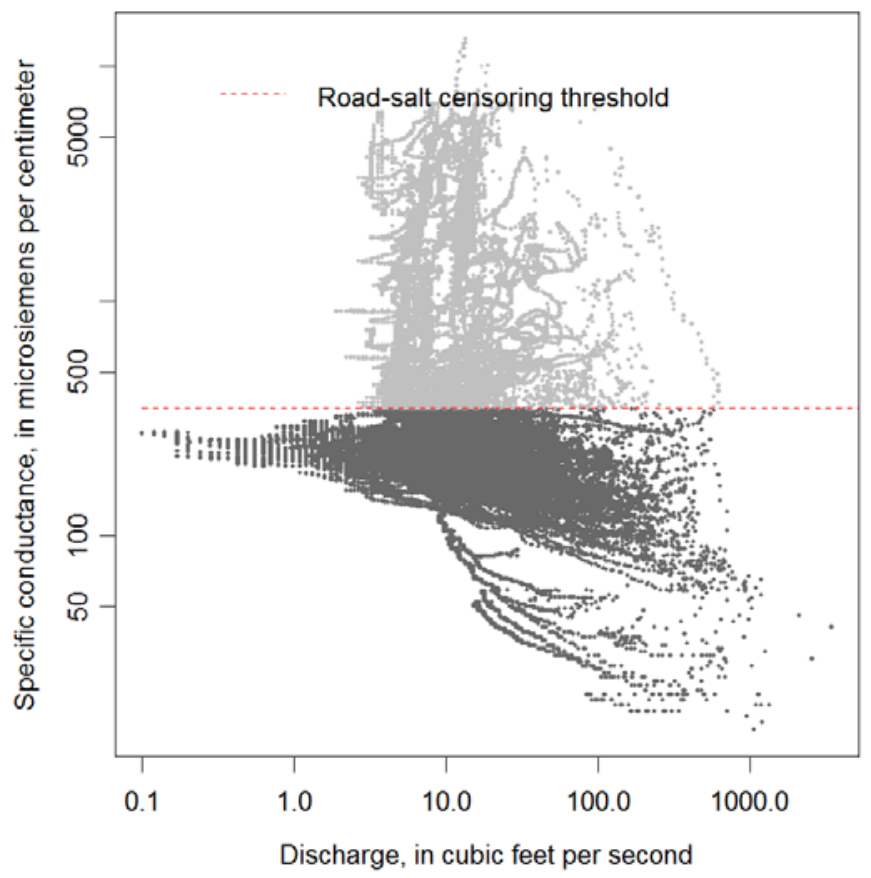

Figure 5. Scatter plot comparing specific conductance to discharge at Paint Branch near College Park, Maryland (USGS station 01649190) during the study period showing the effects of road salt and the cutoff value of 350 microsiemens per centimeter for model censoring. 


\section{Estimation of Constituent Loads}

Annual loads are the mass of a chemical or physical constituent such as nitrogen or sediment that is delivered to a particular point in the river over a specified period of time. They are basically the product of concentration (for example, in units of $\mathrm{mg} / \mathrm{L}$ ), stream discharge at that point (for example, in units of $\mathrm{ft}^{3} / \mathrm{s}$ ), and a units conversion factor:

\[ L_{T}=\int_{t_{0}}^{t_{i}} k C_{i} Q_{i} d t \]
where
$\begin{array}{cl}L_{T} & \text { is the total load over the period of time } T \text {; } \\ C_{i} & \text { is the concentration at time } t_{i} ; \\ Q_{i} & \text { is the stream discharge at time } t_{i} \text {; and } \\ k & \text { is a units conversion factor. }\end{array}$

Whereas discharge is often measured at high frequency, as in the case of the four stations in the current study where it was measured every 15 minutes, concentration data are usually collected less frequently and must be interpolated by regression to other measured parameters to complete the integration for load estimation. The most common predictive variables for concentrations of nutrient and sediment are discharge and time (Cohn, 2005; Cohn and others, 1989), but because of new technology that enables measurement of other common physical parameters of water quality continuously, predictors such as turbidity and SC can greatly improve the precision of loading estimates. Continuous water-quality data were not available for Rock Creek at the time of this study, so the loads for Rock Creek were based solely on flow and time. The likely effect of this was lower precision in the Rock Creek load estimates.

Annual loads for SS, TP, TN, and E. coli were estimated for this report using the USGS program LOADEST for all four stations for water years 2005 through 2011, except for years where there were large gaps in data. LOADEST (Runkel and others, 2004) is based on an earlier log-linear regression model, ESTIMATOR (Cohn, 1988, 2005; Cohn and others, 1989; Cohn and others, 1992); ESTIMATOR uses a FORTRAN code with log-transformed variables to fit a linear regression to estimate concentrations of water-quality constituents from mean daily values of stream discharge, discharge ${ }^{2}$, time, time ${ }^{2}$, and sin(time) and cos(time) terms to approximate seasonality. A Minimum Variance Unbiased Estimator (MVUE) within the model corrects for bias created when data are transformed from log space back to linear space (Bradu and Mundlak, 1970). Centering variables (normalization of each variable to the mean) reduce or eliminate multicollinearity, or non-independence between explanatory variables, and the Adjusted Maximum Likelihood Estimator (AMLE) reduces bias when estimating values from censored data. Whereas ESTIMATOR is calibrated using mean-daily flow (averaged over a 24-hour time step) and uses only flow and time as predictor variables, LOADEST has the advantage of being able to use hourly time steps and to include other variables, such as turbidity, which has been determined in this and other studies to be the best predictor of many water-quality variables. LOADEST also has been shown to improve error estimates and bias over ESTIMATOR (Miller, Gutiérrez-Magness, and others, 2007; Rasmussen and others, 2005; Chanat and others, 2013). Missing data presents a problem for both models. For the current study, estimated values were interpolated using a linear estimate between the two data points for gaps of less than 1 day, and using medians for the entire dataset for larger gaps in time. The variables used for LOADEST modeling were turbidity, discharge, discharge ${ }^{2}$, time, time ${ }^{2}$, sin(time), and cos(time) at hourly time steps.

For comparison purposes, loads were normalized to basin area and reported as yields (kilograms per year per square kilometer or MPN per year per square kilometer). For Rock Creek, the basin area for the site at Sherrill Drive where flow was measured was used for yield calculations. 


\section{Hydrologic Conditions over the Study Period}

Rainfall in the region is generally consistent throughout the year, but seasonal flows peak in the spring and fall with lower average flows in late summer due to increases in evapotranspiration. Monthly summaries of discharge data for the Northeast Branch Anacostia River over the study period are shown in figure 6. Major storm events tend to occur in the spring and fall, but can occur at any time of the year.

Hydrologic conditions over the study period were normal, with the highest mean annual discharge for each site occurring in 2010, but with a higher incidence of major storms and hurricanes occurring in 2011. The top eight daily mean discharge events observed on the Northeast Branch Anacostia River at Riverdale, Maryland (USGS station 01649500) with the meteorological event that triggered the observed high flows during water years 2004 to 2011 are listed in table 5.
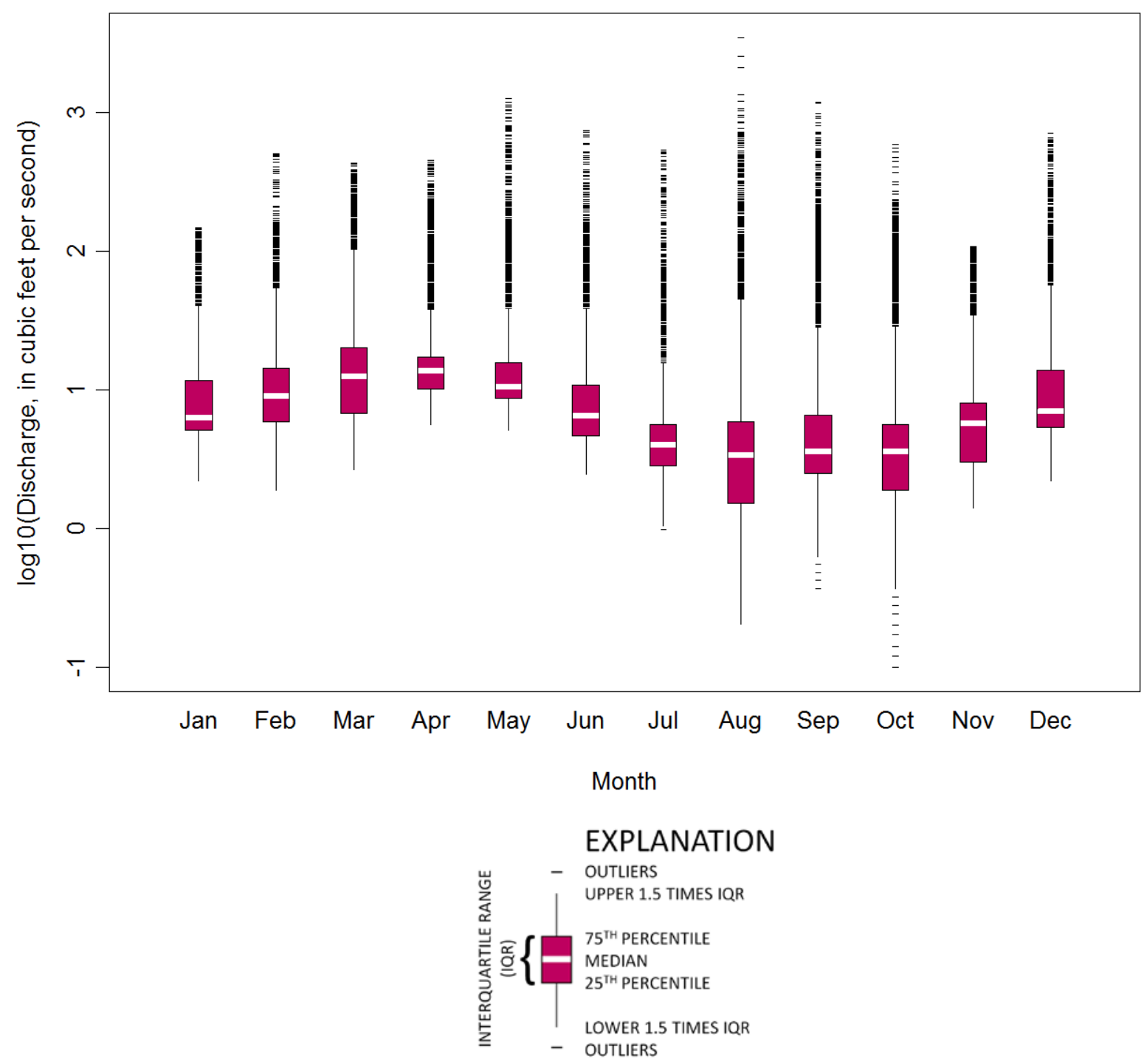

Figure 6. Boxplots comparing monthly summaries of 15-minute-interval discharge data for the Northeast Branch Anacostia River (USGS station 01649500) for water years 2004 through 2011. 
Table 5. Top eight daily mean discharge events for the Northeast Branch Anacostia River at Riverdale, Maryland (USGS station 01649500) for water years 2004-2011.

[Median discharge for this period of record at this station is 40.2 cubic feet per second $\left(\mathrm{ft}^{3} / \mathrm{s}\right)$; Archived radar imagery can be viewed at http://locust.mmm.ucar.edu/. Historical Hurricane information was obtained on October 1, 2012 at http://weather.unisys.com/hurricane/index.php]

\begin{tabular}{ccc} 
Date & $\begin{array}{c}\text { Daily Mean } \\
\text { Discharge }\left(\mathbf{f t}^{3} / \mathbf{s}\right)\end{array}$ & Event \\
\hline 10/8/2005 & 4,321 & Tropical Storm Tammy \\
6/26/2006 & 4,294 & Tropical Storm Ernesto \\
5/12/2008 & 4,051 & Extratropical event \\
9/8/2011 & 2,968 & Tropical Storm Lee \\
9/7/2011 & 2,544 & Tropical Storm Lee \\
$12 / 26 / 2009$ & 2,530 & Large snowmelt event \\
$4 / 15 / 2007$ & 2,438 & Nor'easter \\
$8 / 28 / 2011$ & 2,378 & Hurricane Irene \\
\hline
\end{tabular}

\section{Summary of Water-Quality Data}

Multiple types of water data were collected at the monitoring stations in the Anacostia River and Rock Creek watersheds during this study. Continuous monitoring of flow and physical parameters (table 6) were used in conjunction with discrete sampling for water quality during base-flow and storm events (table 7) to provide a summary of the environmental conditions for both rivers. All water-quality and flow data are available on the USGS NWIS Web site at http://waterdata.usgs.gov/nwis.

Water quality showed strong seasonal patterns (fig. 7) that were not necessarily reflected in seasonal flow patterns (fig. 6). The growth of bacteria is very closely related to temperature, so as expected, numbers of $E$. coli followed seasonal temperatures very closely. Concentrations of SS appeared to start to increase during the spring months, and had the highest ranges in concentrations during the summer. TP, and to a lesser extent, TN, followed similar patterns to SS, strongly indicating that particulates were the dominant transport phases for nutrients in these urbanized streams. This is consistent with earlier observations for the Anacostia River (Miller, GutiérrezMagness, and others, 2007). Increases in nutrients in the summer are likely related to increases in fertilizer usage but may also relate to increases in sediment sources, as nitrogen and particularly phosphorus are primarily transported in particulate phases. Possible explanations for increases in SS could be increases in development activities during the warmer months and (or) increases in the energy in flows during spring freshets that could change bank-erosion patterns, but neither of these connections were investigated in the current study. Chanat and others (2013) found similar patterns in Mattawoman Creek, a small Coastal Plain watershed with less development, but found conversely that particulate nitrogen was the smallest component of total nitrogen as opposed to more typically urban watersheds where particulate organic nitrogen is often the dominant component of TN (Miller, Gutiérrez-Magness, and others, 2007). 
Table 6. Summaries of continuous field parameters for each of the U.S. Geological Survey stations in the Anacostia River and Rock Creek watersheds.

[Continuous data are summarized from data collected during the period of this study (see table 2), and are presented as the median with the minimum and maximum values in parentheses. Continuous water-quality data were not collected at Rock Creek over the study period; $\mathrm{ft}^{3} / \mathrm{s}$, cubic feet per second; ${ }^{\circ} \mathrm{C}$, degrees Celsius; $\mu \mathrm{S} / \mathrm{cm}$, microsiemens per centimeter at $25^{\circ} \mathrm{C}$; mg/L, milligrams per liter, FNU, formazin nephelometric units; <, less than; --, not available]

\begin{tabular}{|c|c|c|c|c|c|c|}
\hline & $\begin{array}{c}\text { Discharge } \\
\left(\mathbf{f t}^{3} / \mathbf{s}\right)\end{array}$ & $\begin{array}{c}\text { Water } \\
\text { Temperature } \\
\left({ }^{\circ} \mathrm{C}\right)\end{array}$ & pH & $\begin{array}{c}\text { Specific } \\
\text { Conductance } \\
(\mu \mathrm{S} / \mathrm{cm})\end{array}$ & $\begin{array}{c}\text { Dissolved } \\
\text { Oxygen } \\
\text { (mg/L) }\end{array}$ & $\begin{array}{c}\text { Turbidity } \\
\text { (FNU) }\end{array}$ \\
\hline \multicolumn{7}{|c|}{ Paint Branch near College Park, Md. (01649190) } \\
\hline $\begin{array}{l}\text { Median } \\
\text { (Range) }\end{array}$ & $\begin{array}{c}6.72 \\
(0.1-3,452)\end{array}$ & $\begin{array}{c}13.2 \\
(0-28.0)\end{array}$ & $\begin{array}{c}7.5 \\
(6.7-8.7)\end{array}$ & $\begin{array}{c}245 \\
(15-13,000)\end{array}$ & $\begin{array}{c}10.4 \\
(6.4-16.7)\end{array}$ & $\begin{array}{c}1.7 \\
(0-1,330)\end{array}$ \\
\hline \multicolumn{7}{|c|}{ Northeast Branch Anacostia River at Riverdale, Md. (01649500) } \\
\hline $\begin{array}{l}\text { Median } \\
\text { (Range) }\end{array}$ & $\begin{array}{c}40.2 \\
(1.5-11,953)\end{array}$ & $\begin{array}{c}14.5 \\
(0-33.6)\end{array}$ & $\begin{array}{c}7.4 \\
(5.2-9.7)\end{array}$ & $\begin{array}{c}315 \\
(34-9,020)\end{array}$ & $\begin{array}{c}10.2 \\
(2.0-20.2)\end{array}$ & $\begin{array}{c}5.8 \\
(0-1140)\end{array}$ \\
\hline \multicolumn{7}{|c|}{ Northwest Branch Anacostia River near Hyattsville, Md. (01651000) } \\
\hline $\begin{array}{l}\text { Median } \\
\text { (Range) }\end{array}$ & $\begin{array}{c}25.6 \\
(0-13,933)\end{array}$ & $\begin{array}{c}15.4 \\
(0-31.8)\end{array}$ & $\begin{array}{c}7.3 \\
(6.5-9.5)\end{array}$ & $\begin{array}{c}368 \\
(57-14,000)\end{array}$ & $\begin{array}{c}9.9 \\
(1.6-19.3)\end{array}$ & $\begin{array}{c}4.2 \\
(0-1,130)\end{array}$ \\
\hline \multicolumn{7}{|c|}{ Rock Creek at Sherrill Drive, D.C. (01648000) } \\
\hline $\begin{array}{l}\text { Median } \\
\text { (Range) }\end{array}$ & $\begin{array}{c}30.2 \\
(0.44-2,173)\end{array}$ & -- & -- & -- & -- & -- \\
\hline
\end{tabular}


Table 7. Summaries of discrete water-quality data for each of the U.S. Geological Survey stations in the Anacostia River and Rock Creek collected over the study period.

[See table 2 for period of record; $\mathrm{mg} / \mathrm{L}$, milligrams per liter; MPN/100 mL, most probable number of viable colony-forming units per 100 milliliters; Range, minimum and maximum values; $n$, number of samples; total nitrogen is calculated as the sum of each sample concentration of total Kjeldahl nitrogen and nitrate/nitrite nitrogen; <, less than; > greater than]

\begin{tabular}{|c|c|c|c|c|c|c|c|}
\hline tations & $\begin{array}{c}\text { Total } \\
\text { Kjeldahl } \\
\text { nitrogen } \\
(\mathrm{mg} / \mathrm{L}) \\
\end{array}$ & $\begin{array}{c}\text { Ammonia } \\
\text { nitrogen } \\
(\mathrm{mg} / \mathrm{L}, \text { as } \mathrm{N})\end{array}$ & $\begin{array}{c}\text { Nitrate/nitrite } \\
\text { nitrogen } \\
(\mathrm{mg} / \mathrm{L}, \text { as } N)\end{array}$ & $\begin{array}{c}\text { Total } \\
\text { nitrogen } \\
(\mathrm{mg} / \mathrm{L})\end{array}$ & $\begin{array}{c}\text { Total } \\
\text { phosphorus } \\
(\mathrm{mg} / \mathrm{L})\end{array}$ & $\begin{array}{c}\text { E. coli } \\
(\mathrm{MPN} / 100 \mathrm{~mL})\end{array}$ & $\begin{array}{c}\text { Suspended } \\
\text { Sediment } \\
(\mathrm{mg} / \mathrm{L}) \\
\end{array}$ \\
\hline \multicolumn{8}{|c|}{ Paint Branch near College Park, Md. (01649190) } \\
\hline $\mathrm{n}$ & 182 & 156 & 183 & 182 & 182 & & \\
\hline & .79 & .02 & & 1.6 & .12 & & \\
\hline ge) & $.05-5.8)$ & $(<.01-.322)$ & $(.15-2.67)$ & $(.62-6.51)$ & $(<.01-0.85)$ & $(<10-$ & $(<.5-4,3$ \\
\hline \multicolumn{8}{|c|}{ Northeast Branch Anacostia River at Riverdale, Md. (01649500) } \\
\hline & 179 & 178 & 178 & 178 & 179 & 150 & 21 \\
\hline dian & 1.3 & .052 & .62 & 1.8 & 0.22 & 5,100 & 170 \\
\hline & $(.18-5.1)$ & $(<.005-.53)$ & $(.17-1.4)$ & $(.48-5.7)$ & $(.01-1.05)$ & $(36-120,000)$ & (1) \\
\hline \multicolumn{8}{|c|}{ Northwest Branch Anacostia River near Hyattsville, Md. (01651000) } \\
\hline & 129 & & & 127 & 129 & 92 & \\
\hline dian & 1.6 & 0.047 & 0.73 & 2.2 & 0.3 & 3,050 & 160 \\
\hline & $16-5.1)$ & $(<.006-.50$ & $(.17-2.0)$ & $(.82-5.9)$ & $(<.009-.93)$ & $(33->2$ & $(2-1,70$ \\
\hline \multicolumn{8}{|c|}{ Rock Creek at Joyce Road, D.C. (01648010) } \\
\hline & 227 & & & 223 & 230 & & 23 \\
\hline Pding & 1 & 0.044 & 0.68 & 1.9 & 0.16 & 3,400 & 120 \\
\hline (Range) & $(.24-6.0)$ & $(<.01-1.2)$ & $(<.03-3.5)$ & $(.63-6.3)$ & $(<.004-1.2)$ & $(2->61,000)$ & $(<.5-3,100)$ \\
\hline
\end{tabular}


(A)

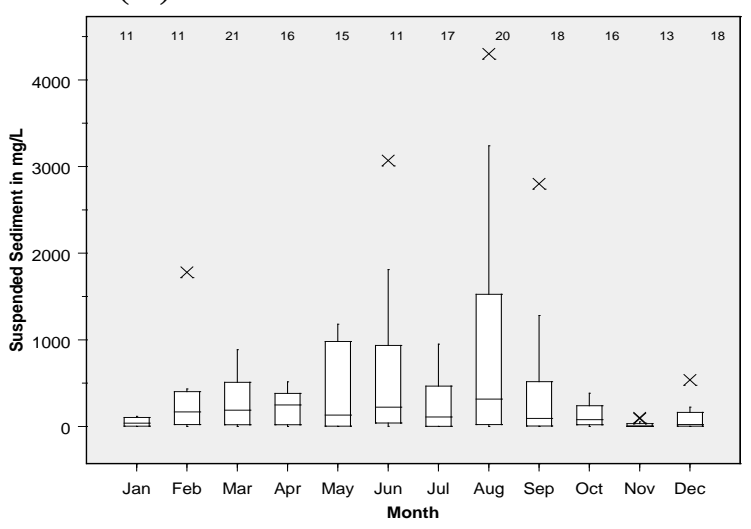

(C)

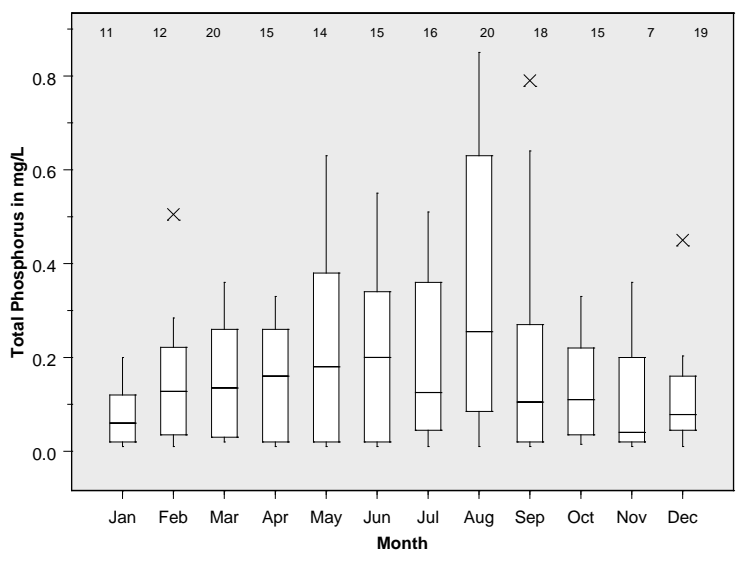

(B)

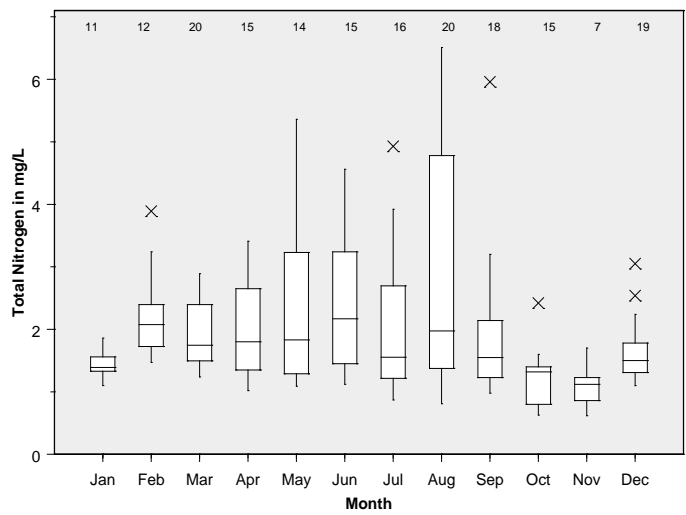

(D)

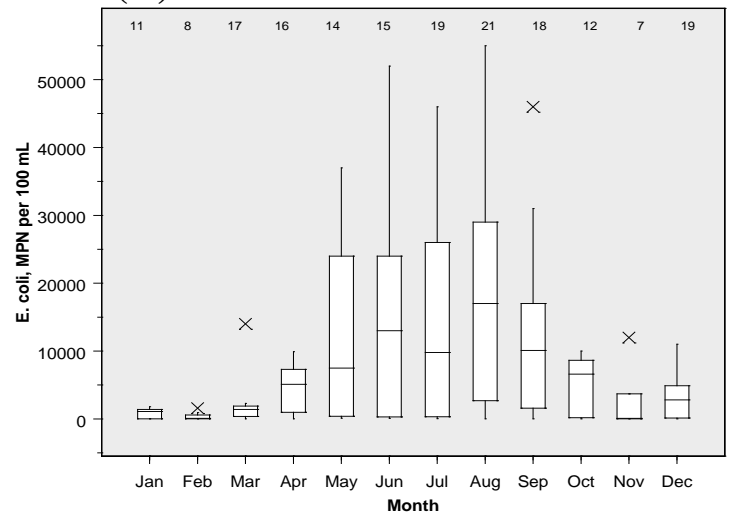

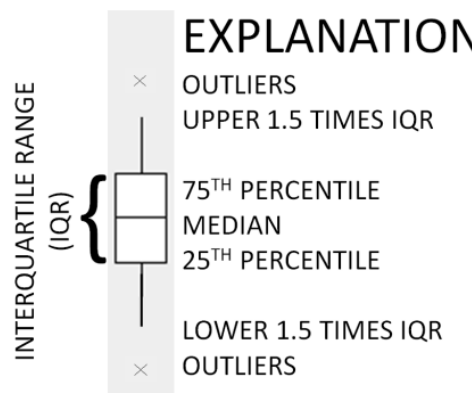

Figure 7. Boxplots comparing monthly summaries of discrete water-quality data for Paint Branch near College Park, Maryland (USGS station 01649190) for water years 2008 to 2011. Concentrations of (A) suspended sediment in milligrams per liter, (B) total nitrogen in milligrams per liter, (C) total phosphorus in milligrams per liter, and (D) E. coli in most probable number of viable colony-forming units per 100 milliliters. 


\section{Multiple Regression Analysis}

Multiple log-linear regression models were developed to estimate concentrations of SS, TN, TP, and E. coli from physical parameters. The first step in this process was to evaluate all relations between parameters in terms of predictive power, scatter and bias from outliers, and transformations that improved the normality of the datasets. Transformations to base-10 logarithms provided the most linear relations, normal distributions, and the most constant variance except for a few outliers in each dataset. The models were calculated separately with the most influential outliers removed, to determine whether they had an effect on the selection of predictor variables. In both cases, with and without the outliers, stepwise regression selected the same model. With the outliers removed, the residuals were smaller with higher $\mathrm{R}^{2}$ values, but the datasets were still not normal. Therefore, according to the recommendations of Helsel and Hirsch (1992, table 9.1), outlier values were included in the final models. As an example of the modeling process, scatter plots for all of the parameters being tested on the Paint Branch station are shown in figure 8, and a matrix of Pearson linear correlation coefficients for these same relations is shown in table 8 . All parameters were log-transformed, except for temperature, which varied over a small range of values without outliers, and $\mathrm{pH}$, which is already a log-transformed parameter.

As expected, turbidity was a good predictor variable for most of the water-quality parameters, with $\mathrm{R}^{2}$ for the log-concentrations of SS, TP, and E .coli ranging from .85 to .93. Similarly, Jastram and others (2009) did a very in-depth comparison of turbidity- and streamflow-based models to estimate concentrations of SS, TN, and TP and found that using turbidity rather than traditional models based on streamflow as the primary predictor variable significantly decreased the errors of the estimates.

In the current study, the correlation coefficient between log-TN and log-turbidity was lower than for the other three relations, and the upward-concave shape of the scatter plot indicates a non-linear relation. The regression equations for TN were improved for the Northwest Branch Anacostia River and Paint Branch by adding a squared term and then centering the variables by subtracting the mean of the log of all of the observations. The centering adjustment mitigated colinearity when both linear $(\mathrm{x})$ and squared $\left(\mathrm{x}^{2}\right)$ terms were included in the model. For Northwest Branch and Paint Branch, the values of the mean $\log _{10}$ (Turb) were 1.7607 and 1.5013, respectively. For bacteria, a second parameter, temperature, improved the relation enough to be left in the regression equation for all three Anacostia River sites, which made physical sense given the temperature dependence of bacterial metabolism as observed by the strong seasonal patterns in numbers of bacteria (fig. 7D).

Regression models for SS, TP, TN, and E. coli with $\mathrm{R}^{2}$ and bias corrections are presented in table 9 . The values of $\mathrm{R}^{2}$ are calculated on log-transformed values and variances may increase when values are transformed back to real space, especially for outlier concentrations.

Plots of two storms in April 2009 and September 2010 at Paint Branch show a comparison of concentrations of SS, TN, TP, and E. coli estimated by the regression models and measured discrete concentrations (fig. 9). These two storms provide some contrast of results for a spring and a fall storm and show the effects of different storm intensities. Scatter plots of the entire dataset demonstrate the spread and bias across the ranges of concentrations (fig. 10). As for similar models (Miller, Gutiérrez-Magness, and others, 2007; Chanat and others, 2013), estimates of SS and TP based on turbidity are the most accurate, because turbidity has a direct physical relation to suspended material in the water column, and phosphate partitions strongly into the particulate phase. The models appeared to predict peak concentrations very well, but were sometimes less accurate on the receding limbs of the hydrographs, where due to hysteretic effects, the models tended to overpredict concentrations. The noise in the predicted values of TN during the latter part of the September storm was an artifact of the model where small changes in turbidity were amplified in the log-turbidity-squared term. The models for E. coli were less accurate for predicting individual concentrations (figs. 9G,H). Measurements of the number of $E$. coli tend to be difficult to reproduce because of high spatial variability in the water column. Thus, even though coefficients of determination were in the range of 0.75 to 0.82 , predictions of individual concentrations of bacteria are not recommended. In fact, Rasmussen and Ziegler (2003) suggested reporting estimated levels of bacteria as probabilities of exceeding regulated thresholds rather than concentrations because of high variability in individual measurements. 


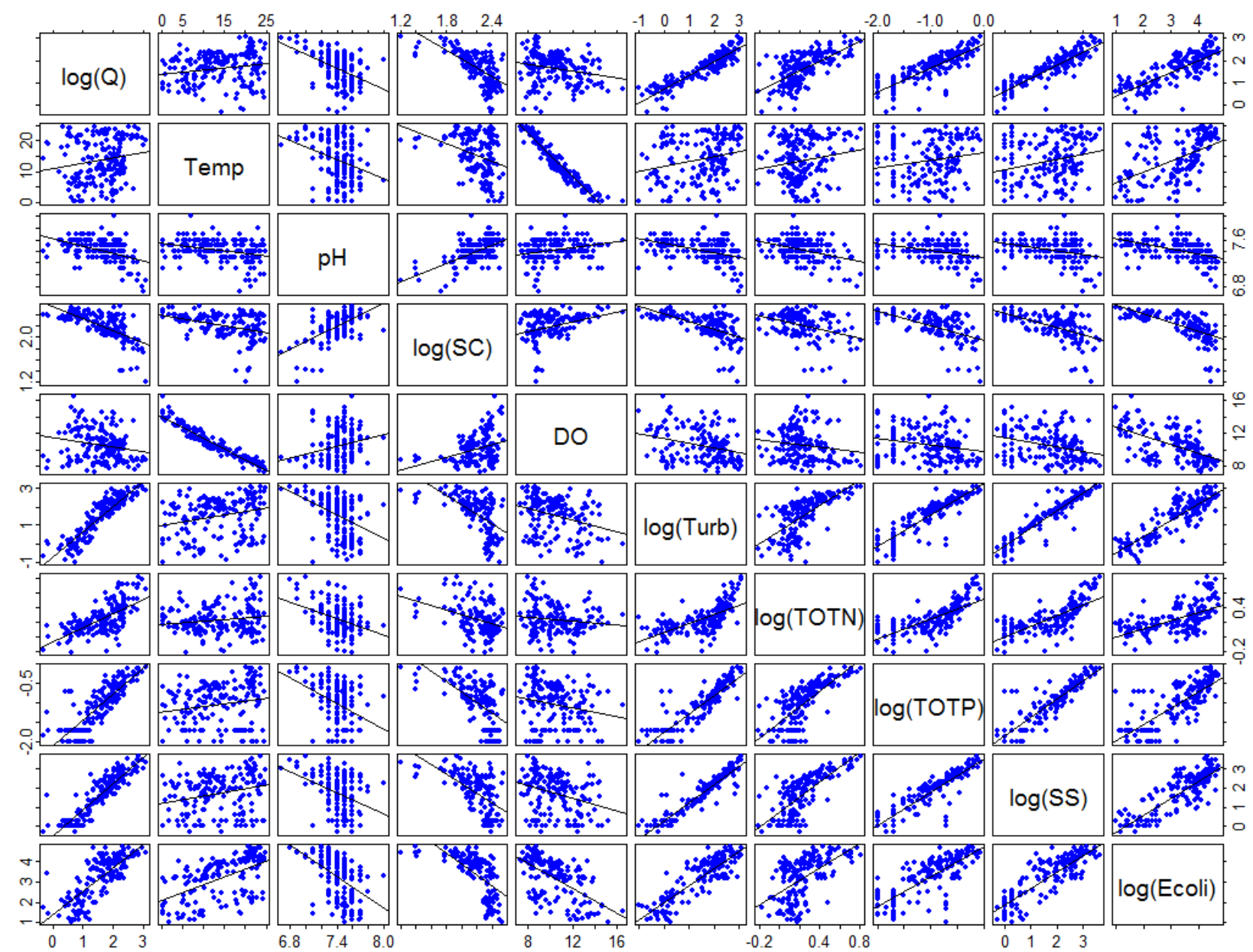

Figure 8. Scatter plots comparing continuous physical parameters and discrete water quality for Paint Branch near College Park, Maryland (USGS station 01649190), including all data from automatic samplers and equal-width increment (EWI) sampling, showing correlations and spread for each relation. Simple least-square fits to the data are drawn for each plot. The axes for each plot correspond to the parameter in the diagonal of that row or column and the units for parameter are at the top or bottom of the row or column. [log, base 10 logarithm of variable; Q, discharge in cubic feet per second; Temp, temperature in degrees Celsius; SC, specific conductance in microsiemens per centimeter; DO, dissolved oxygen in milligrams per liter (mg/L); Turb, turbidity in formazin nephelometric units (FNU); TOTN, total nitrogen in mg/L; TOTP, total phosphorus in $\mathrm{mg} / \mathrm{L}$; SS, suspended sediment in mg/L; Ecoli, most probable number (MPN) of viable colony-forming units of colony-forming units per 100 milliliters] 
Table 8. Table of Pearson correlation coefficients for Paint Branch near College Park, Maryland (USGS station 01649190).

[Continuous physical parameters are compared to discrete water-quality parameters. Values for parameters that were used in the regression models are in bold; Q, stream discharge; Temp, temperature; SC, specific conductance; DO, concentration of dissolved oxygen; Turb, turbidity; TN, concentration of total nitrogen; $\mathrm{TP}$, concentration of total phosphorus; SS, concentration of suspended sediment]

\begin{tabular}{|c|c|c|c|c|c|c|c|c|c|c|}
\hline Parameters & $\log _{10}(\mathrm{Q})$ & Temp & $\mathrm{pH}$ & $\log _{10}(\mathrm{SC})$ & DO & $\log _{10}$ (Turb) & $\log _{10}(\mathrm{TN})$ & $\log _{10}(\mathrm{TP})$ & $\log _{10}(\mathrm{SS})$ & $\log _{10}$ (E. coli) \\
\hline $\log _{10}(Q)$ & 1 & & & & & & & & & \\
\hline Temp & .16 & 1 & & & & & & & & \\
\hline $\mathrm{pH}$ & -.47 & -.30 & 1 & & & & & & & \\
\hline $\log _{10}(\mathrm{SC})$ & -.69 & -.33 & .63 & 1 & & & & & & \\
\hline DO & -.21 & -.97 & .25 & .33 & 1 & & & & & \\
\hline $\log _{10}$ (Turb) & .91 & .24 & -.42 & -.59 & -.32 & 1 & & & & \\
\hline $\log _{10}(\mathrm{TN})$ & .63 & .16 & -.34 & -.39 & -.16 & .62 & 1 & & & \\
\hline $\log _{10}(\mathrm{TP})$ & .83 & .20 & -.35 & -.60 & -.23 & .87 & .73 & 1 & & \\
\hline $\log _{10}(\mathrm{SS})$ & .89 & .24 & -.35 & -.59 & -.30 & .93 & .77 & .93 & 1 & \\
\hline $\log _{10}($ E. coli $)$ & .76 & .51 & -.45 & -.62 & -.57 & .85 & .56 & .79 & .86 & 1 \\
\hline
\end{tabular}


Table 9. Summary of regression models for the Northeast (NE) Branch Anacostia River at Riverdale, Maryland (USGS station 01649500), the Northwest (NW) Branch Anacostia River near Hyattsville, Maryland (USGS station 01651000), and Paint Branch near College Park, Maryland (USGS station 01649190).

[mg/L, milligrams per liter; SS, concentration of suspended sediment in $\mathrm{mg} / \mathrm{L}$; TP, concentration of total phosphorus in mg/L; TN, concentration of total nitrogen in mg/L; EC, E. coli bacteria in MPN; MPN, most probable number of viable colony-forming units per 100 milliliters (mL); MA, mean-adjusted observations; Temp, water temperature; $n$, number of sample-pair observations; $\mathrm{R}^{2}$, coefficient of determination; \%, percent; $\log _{10}$ TurbMA, the "Mean-Adjusted" $\log _{10}$ turbidity for each observation, defined as the $\log _{10}$ (Turb) minus the mean of $\log _{10}($ Turb) over all observations. For Northwest Branch and Paint Branch, the mean $\log _{10}$ (Turb) are 1.7607 and 1.5013, respectively.]

\begin{tabular}{|c|c|c|c|c|c|}
\hline Constituent & Watershed & Equation & $\begin{array}{c}\text { Adjusted } \\
\mathbf{R}^{2} \\
\end{array}$ & $\mathbf{n}$ & $\begin{array}{c}\text { Corrected } \\
\text { bias }(\%)^{1}\end{array}$ \\
\hline \multirow{3}{*}{$\begin{array}{l}\text { Suspended } \\
\text { Sediment } \\
\text { (mg/L) }\end{array}$} & NE Branch & $\log _{10}(\mathrm{SS})=0.1005+1.0618 * \log _{10}($ Turb $)$ & 0.93 & 197 & 10.5 \\
\hline & NW Branch & $\log _{10}(\mathrm{SS})=0.1851+1.0373 * \log _{10}($ Turb $)$ & 0.91 & 138 & 40.1 \\
\hline & Paint Branch & $\log _{10}(\mathrm{SS})=0.3167+0.9359 * \log _{10}($ Turb $)$ & 0.88 & 166 & 22.8 \\
\hline \multirow{3}{*}{$\begin{array}{l}\text { Total } \\
\text { Phosphorus } \\
\text { (mg/L) }\end{array}$} & NE Branch & $\log _{10}(T P)=-1.7717+0.5303 * \log _{10}($ Turb $)$ & 0.86 & 167 & 1.6 \\
\hline & NW Branch & $\log _{10}(T P)=-1.8424+0.6113 * \log _{10}($ Turb $)$ & 0.89 & 118 & 2.1 \\
\hline & Paint Branch & $\log _{10}(T P)=-1.7272+0.4675 * \log _{10}($ Turb $)$ & 0.80 & 166 & 3.5 \\
\hline \multirow{3}{*}{$\begin{array}{l}\text { Total } \\
\text { Nitrogen } \\
(\mathrm{mg} / \mathrm{L})\end{array}$} & NE Branch & $\log _{10}(T N)=-0.0688+0.1816^{*} \log _{10}($ Turb $)$ & 0.54 & 166 & -0.2 \\
\hline & NW Branch & $\log _{10}(\mathrm{TN})=0.2888+0.2240 * \log _{10}($ TurbMA $)+0.0653 * \log _{10}(\text { TurbMA })^{2}$ & 0.63 & 116 & -0.2 \\
\hline & Paint Branch & $\log _{10}(T N)=0.1638+0.1758 * \log _{10}($ TurbMA $)+0.0764 * \log _{10}(\text { TurbMA })^{2}$ & 0.56 & 166 & -0.7 \\
\hline \multirow{3}{*}{$\begin{array}{l}\text { E. coli } \\
\text { Bacteria } \\
\text { (MPN/100 mL) }\end{array}$} & NE Branch & $\log _{10}(E C)=1.4938+0.8226 * \log _{10}($ Turb $)+0.0369 * T e m p$ & 0.77 & 146 & 39.8 \\
\hline & NW Branch & $\log _{10}(E C)=1.7093+0.7808 * \log _{10}($ Turb $)+0.0373 *$ Temp & 0.75 & 89 & 17.1 \\
\hline & Paint Branch & $\log _{10}(E C)=1.5254+0.7636 * \log _{10}($ Turb $)+0.0052 *$ Temp & 0.82 & 161 & 62.9 \\
\hline
\end{tabular}

${ }^{1}$ Reported values include application of Duan's "smearing correction"; see Helsel and Hirsch, 1992, sec. 9.6.2 and 9.6.3. 

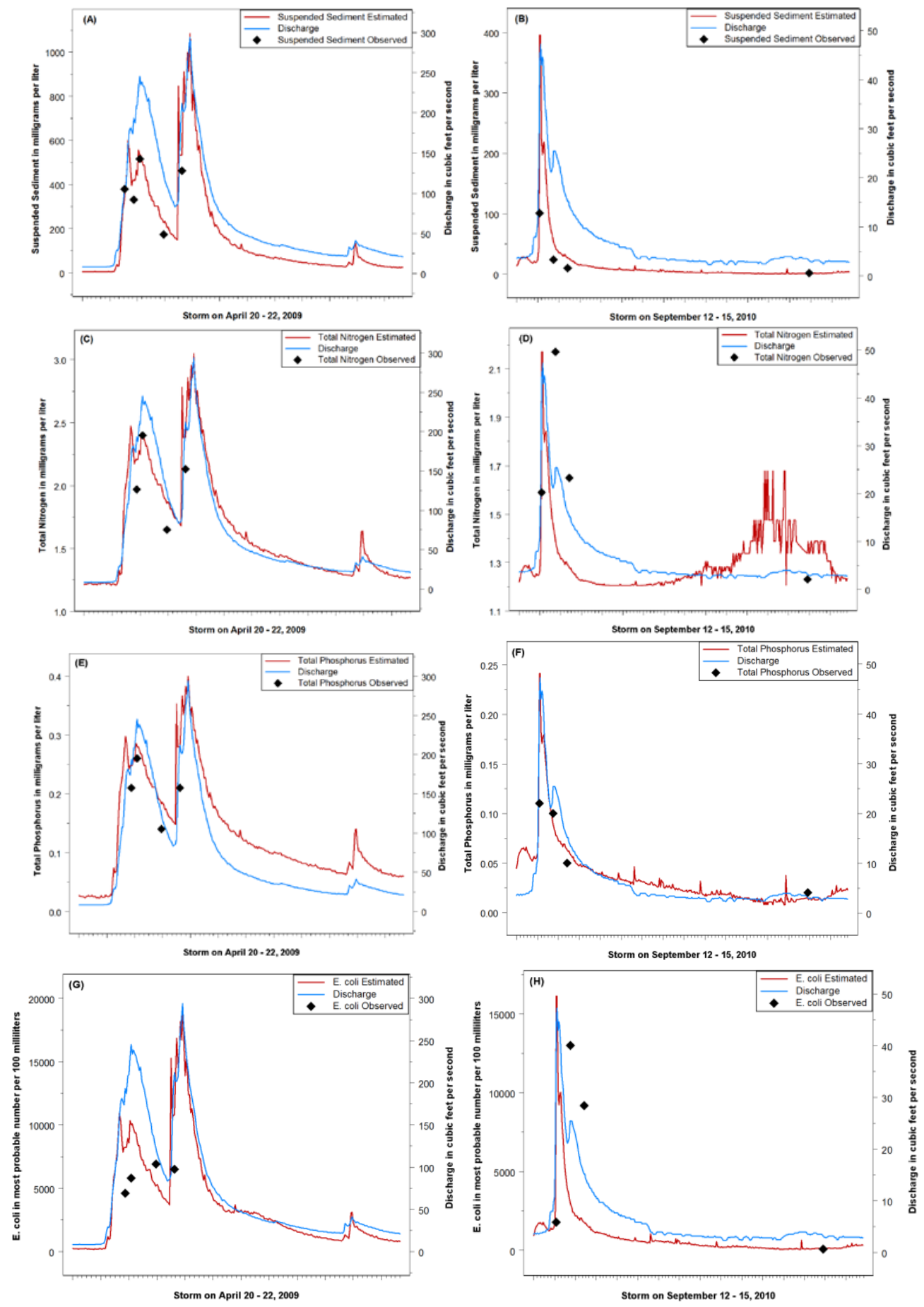

Figure 9. Time-series plots comparing estimated and measured concentrations of (A,B) suspended sediment, $(\mathrm{C}, \mathrm{D})$ total nitrogen, $(\mathrm{E}, \mathrm{F})$ total phosphorus, and $(\mathrm{G}, \mathrm{H}) \mathrm{E}$. coli with an overlay of discharge during two storm events for Paint Branch near College Park, Maryland (USGS station 01649190). 

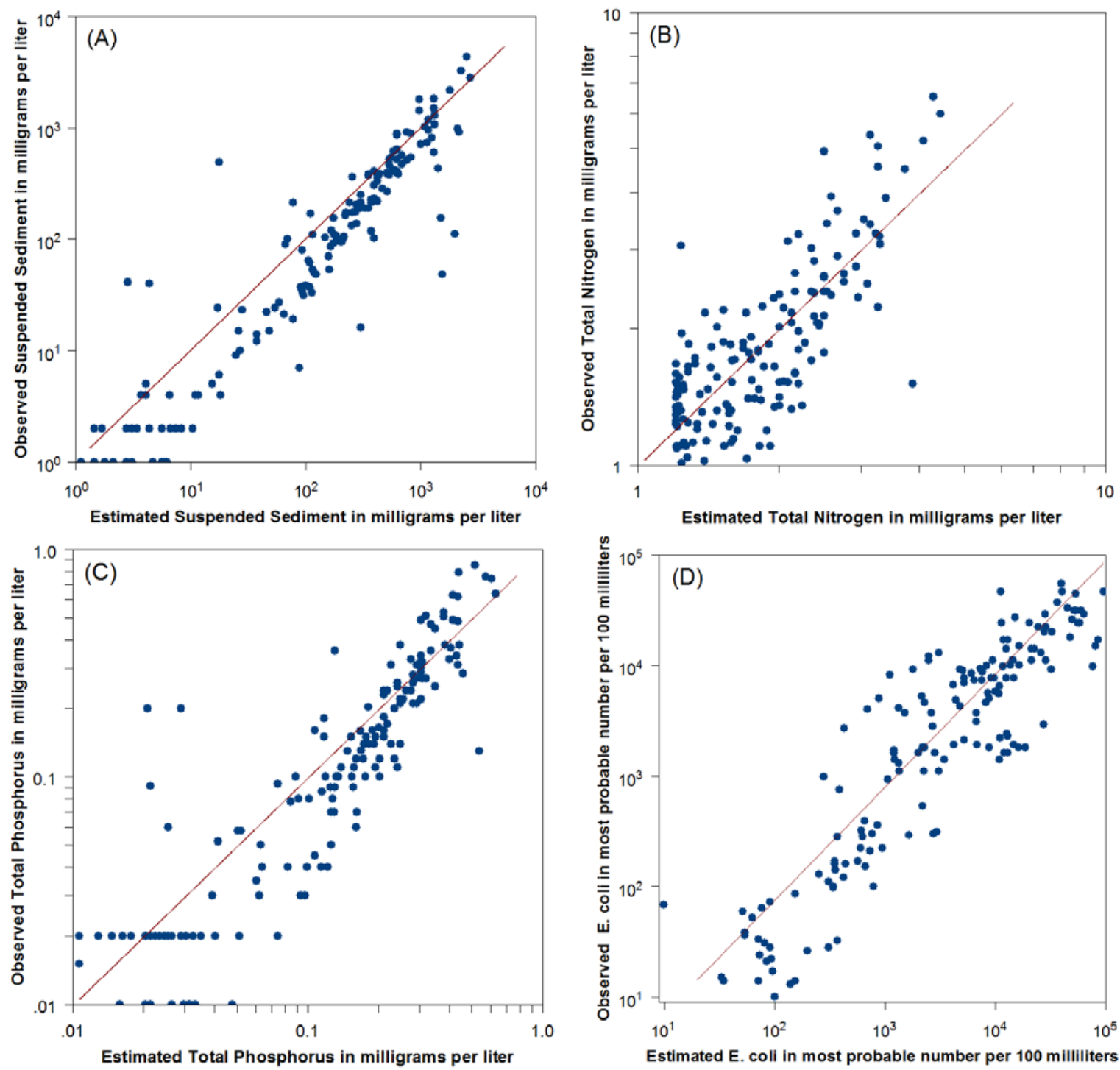

Figure 10. Scatter plots comparing estimated and observed concentrations of (A) suspended sediment, (B) total nitrogen, (C) total phosphorus, and (D) E. coli for Paint Branch near College Park, Maryland (USGS station 01649190), using the model equations and bias corrections provided in table 9. [mg/L, milligrams per liter; mL, milliliters; MPN, most probable number of viable colony-forming units per 100 milliliters] 


\section{Loading Estimates}

Estimates of loads were calculated using both ESTIMATOR and LOADEST and compared to obtain estimates with the least bias and uncertainty. On the basis of results of multiple regression-model testing that determined turbidity to be the best predictive variable for all for water-quality constituents, the load estimates using LOADEST with turbidity as the main independent variable had smaller residual errors than those made with ESTIMATOR; thus, only the results from the LOADEST models are presented here. Annual loads for each of the USGS water-quality-monitoring stations in this study are summarized in table 10. Annual loads were calculated for every water year where there was a full year of continuous flow and turbidity data, and discrete samples had been collected over base-flow and storm conditions for each parameter of interest. Averages of annual loads for each station are presented. Load estimates from the State and County TMDL reports (Maryland Department of the Environment, 2007a,b, 2008a,b, 2011, 2012) and the Anacostia Watershed Restoration Plan (U.S. Army Corps of Engineers, 2010) have been converted to the same units used in this report and provide comparison and context for loads at the USGS stations. The U.S. Army Corps of Engineers (USACE) used the same dataset as the TMDL reports, but re-computed the Hydrological Simulation Program-Fortran (HSPF) models at the subwatershed scale with an added land-use layer for road cover. Differences in methodologies for the water-quality parameters must be considered when making comparisons among the load results shown in table 10. Most notably, the bacterial loads by USGS were based on E. coli and the State and USACE used measurements of enterococci. Both $E$. coli and enterococci are components of total fecal-coliform bacteria loads and are good indicators of safety thresholds for human health. Concentrations of each are often similar in magnitude, but they can vary significantly from each other as sources and hydrologic conditions differ (Jin and others, 2004). There also are differences in watershed areas used for the different models; USGS loads were calculated for subwatersheds of the Anacostia River, whereas some of the loads from TMDL reports include the lower tidal areas of the Anacostia River. The watershed areas used for Rock Creek load estimates are more similar, including most of the nontidal watershed, but loads were calculated based on different sampling locations. Finally, differences in sampling designs, such as representativeness of sampling over the ranges of hydrologic and seasonal conditions, and collection methods, all affect the summary of water-quality conditions. As expected due to the described differences in monitoring and modeling approaches, there is considerable variability among the load estimates in table 10, but most of the estimates are still within errors of the model outputs.

Estimates of annual load in the current study were normalized to basin area and are presented in table 11 as "yields" (for example in kilograms per year per square mile, $\mathrm{kg} / \mathrm{yr} / \mathrm{mi}^{2}$ ) so that the results from each site could be more easily compared. The 95-percent confidence intervals of the modeled load estimates are presented with each value, and within these confidence intervals, the loads are indistinguishable between sites. The yields for SS, $\mathrm{TN}$, and TP have not been adjusted for flow, so comparisons between years and trends cannot be made due to the strong correlation between load and flow (Langland and others, 2006). In addition, detection of statistically significant trends requires a minimum of 10 years of data (Langland and others, 2012). 
Table 10. Summary of annual loads for suspended sediment, total nitrogen, total phosphorus, and bacteria for the Anacostia River at three stations: Northeast Branch Anacostia River at Riverdale, Maryland (USGS station 01649500); Northwest Branch Anacostia River near Hyattsville, Maryland (01651000); Paint Branch near College Park, Maryland (01649190); and for one combined station on Rock Creek: Rock Creek at Joyce Road , Washington, D.C. (01648010, for water quality) and Rock Creek at Sherrill Drive, Washington, D.C. (01648000, for flow).

[For USGS station estimates, annual loads were calculated where data were available for the full water year, and presented below as averages of those estimates. Results from State and County TMDL development and the Anacostia Watershed Restoration Plan (ARP) are presented for comparison; kg, kilograms; km, kilometers; MPN, most probable number of viable colony-forming units per 100 milliliters; yr, year; --, not available]

\begin{tabular}{|c|c|c|c|c|c|}
\hline $\begin{array}{l}\text { Annual } \\
\text { Load } \\
\text { Estimates }\end{array}$ & $\begin{array}{c}\text { Suspended } \\
\text { sediment } \\
\mathrm{kg} / \mathrm{yr}\end{array}$ & $\begin{array}{c}\text { Total nitrogen } \\
\mathrm{kg} / \mathrm{yr}\end{array}$ & $\begin{array}{c}\text { Total } \\
\text { phosphorus } \\
\mathrm{kg} / \mathrm{yr}\end{array}$ & $\begin{array}{c}\frac{\boldsymbol{E . ~ c o l i ~}^{3}}{\text { MPN/yr }} \\
\text { (in billions) }\end{array}$ & $\begin{array}{c}\text { Enterococci }^{3} \\
\mathrm{MPN} / \mathrm{yr} \\
\text { (in billions) }\end{array}$ \\
\hline \multicolumn{6}{|c|}{ Anacostia River } \\
\hline 01649500 & $21,000,000$ & 142,000 & 14,200 & $4,450,000$ & -- \\
\hline 01651000 & $14,300,000$ & 98,200 & 10,700 & $2,940,000$ & -- \\
\hline 01649190 & $3,650,000$ & 21,100 & 1,550 & 323,000 & -- \\
\hline $\begin{array}{l}\text { Maryland } \\
\text { State } \\
\text { Baseline }^{1}\end{array}$ & $42,600,000$ & 430,000 & 47,300 & -- & $1,166,000^{2}$ \\
\hline TMDL $^{1}$ & $6,440,000$ & 69,800 & 6,980 & -- & 113,000 \\
\hline $\begin{array}{c}\text { ARP } \\
\text { Baseline }^{4}\end{array}$ & $14,700,000$ & 407,000 & 36,600 & -- & -- \\
\hline $\begin{array}{l}\text { ARP } \\
\text { Goal }^{4}\end{array}$ & $2,210,000$ & 85,500 & 7,310 & -- & -- \\
\hline \multicolumn{6}{|c|}{ Rock Creek } \\
\hline 01648010 & $20,300,000$ & 122,000 & 14,300 & $2,650,000$ & \\
\hline $\begin{array}{c}\text { State } \\
\text { Baseline }^{5}\end{array}$ & $14,100,000$ & -- & 20,100 & -- & $1,440,000$ \\
\hline TMDL $^{5}$ & $9,710,000$ & -- & 7,360 & -- & 45,600 \\
\hline \multicolumn{6}{|c|}{$\begin{array}{l}{ }^{1} \text { Annual Maryland State baseline loads and Total Maximum Daily Loads (TMDLs) for suspended sediment, total nitrogen, } \\
\text { and total phosphorus in the Anacostia River are based on Hydrological Simulation Program-Fortran (HSPF) modeling of } \\
\text { source estimates and include the entire watershed (Maryland Department of the Environment, 2007b, 2008a). } \\
{ }^{2} \text { Baseline loads and TMDLs for enterococci in the Anacostia River are the sum of estimates for the subwatersheds of } \\
\text { Northeast and Northwest Branches above their confluence (Maryland Department of the Environment, 2008b). } \\
{ }^{3} \text { Loads for bacteria are calculated for E. coli by USGS and for enterococci using State estimates. } \\
{ }^{4} \text { Estimates of loading and reduction goals are from the Anacostia Watershed Restoration Plan (U.S. Army Corps of } \\
\text { Engineers, 2010). } \\
\text { 5State baseline loads and TMDLs for Rock Creek were determined for the watershed above the Maryland/Washington, D.C. } \\
\text { boundary (Maryland Department of the Environment, 2007a, 2011, 2012). }\end{array}$} \\
\hline
\end{tabular}


Table 11. Estimates of annual yields (loads per square area) for suspended sediment, total nitrogen, total phosphorus, and E. coli for the Anacostia River (USGS stations 01649190, 01649500, and 01651000) and Rock Creek (USGS stations 01648010 (water quality) and 01648000 (flow) for data collected variously in water years 2005 to 2011.

[The 95-percent confidence interval is in parentheses below each value; $\mathrm{ft}^{3} / \mathrm{s}$, cubic feet per second; kg, kilograms; yr, year; $\mathrm{km}^{2}$, square kilometers; MPN, most probable number of viable colony-forming units; --, not available due to partial years of missing data]

\begin{tabular}{|c|c|c|c|c|c|}
\hline $\begin{array}{l}\text { Water } \\
\text { Year } \\
\end{array}$ & $\begin{array}{c}\text { Mean Annual } \\
\text { Flow } \\
\left(\mathrm{ft}^{3} / \mathrm{s}\right)\end{array}$ & $\begin{array}{c}\text { Suspended sediment } \\
\left(\mathrm{kg} / \mathrm{yr} / \mathrm{km}^{2}\right)\end{array}$ & $\begin{array}{c}\text { Total nitrogen } \\
\left(\mathrm{kg} / \mathrm{yr} / \mathrm{km}^{2}\right)\end{array}$ & $\begin{array}{c}\text { Total } \\
\text { phosphorus } \\
\left(\mathrm{kg} / \mathrm{yr} / \mathrm{km}^{2}\right) \\
\end{array}$ & $\begin{array}{c}\text { E. coli } \\
\text { (MPN/yr } / \mathrm{km}^{2} \\
\text { in billions) } \\
\end{array}$ \\
\hline \multicolumn{6}{|c|}{ Paint Branch near College Park, Md. (01649190) } \\
\hline 2008 & 10.5 & $\begin{array}{c}65,500 \\
(39,200-103,000)\end{array}$ & $\begin{array}{c}465 \\
(417-518)\end{array}$ & $\begin{array}{c}37 \\
(29-45)\end{array}$ & $\begin{array}{c}6,000 \\
(4,000-8,800)\end{array}$ \\
\hline 2009 & 12.4 & $\begin{array}{c}117,000 \\
(60,900-204,000)\end{array}$ & $\begin{array}{c}569 \\
(518-624)\end{array}$ & $\begin{array}{c}36 \\
(29-45)\end{array}$ & $\begin{array}{c}7,300 \\
(4,600-11,000)\end{array}$ \\
\hline 2010 & 17.1 & $\begin{array}{c}135,000 \\
(88800-196000)\end{array}$ & $\begin{array}{c}794 \\
(733-858)\end{array}$ & $\begin{array}{c}53 \\
(45-63)\end{array}$ & $\begin{array}{c}13,000 \\
(8.600-18,000)\end{array}$ \\
\hline 2011 & 13.6 & $\begin{array}{c}113,000 \\
(52,100-214,000)\end{array}$ & $\begin{array}{c}656 \\
(591-725)\end{array}$ & $\begin{array}{c}56 \\
(43-72)\end{array}$ & $\begin{array}{c}12,000 \\
(7,400-19,000)\end{array}$ \\
\hline \multicolumn{6}{|c|}{ Northeast Branch Anacostia River at Riverdale, Md. (01649500) } \\
\hline 2005 & 89.7 & $\begin{array}{c}91,000 \\
(75,000-109,000)\end{array}$ & $\begin{array}{c}747 \\
(696-800)\end{array}$ & $\begin{array}{c}70 \\
(63-78)\end{array}$ & $\begin{array}{c}38,000 \\
(23,000-61,000)\end{array}$ \\
\hline 2006 & 97.4 & -- & -- & -- & -- \\
\hline 2007 & 76.5 & $\begin{array}{c}67,700 \\
(55,200-82,300)\end{array}$ & $\begin{array}{c}593 \\
(545-645)\end{array}$ & $\begin{array}{c}51 \\
(45-58)\end{array}$ & $\begin{array}{c}12,000 \\
(8,300-16,000)\end{array}$ \\
\hline 2008 & 93.9 & - & - & - & - \\
\hline 2009 & 88.1 & $\begin{array}{c}166,000 \\
(134,000-204,000)\end{array}$ & $\begin{array}{c}763 \\
(711-818)\end{array}$ & $\begin{array}{c}87 \\
(78-96)\end{array}$ & $\begin{array}{c}26,000 \\
(19,000-34,000)\end{array}$ \\
\hline 2010 & 114.3 & $\begin{array}{c}113,000 \\
(95,300-133,000)\end{array}$ & $\begin{array}{c}854 \\
(798-912)\end{array}$ & $\begin{array}{c}81 \\
(74-89)\end{array}$ & $\begin{array}{c}19,000 \\
(14,000-25,000)\end{array}$ \\
\hline 2011 & 97.6 & $\begin{array}{c}117,000 \\
(925,00-147,000)\end{array}$ & $\begin{array}{c}791 \\
(725-861)\end{array}$ & $\begin{array}{c}85 \\
(75-97)\end{array}$ & $\begin{array}{c}23,000 \\
(15,000-33,000)\end{array}$ \\
\hline \multicolumn{6}{|c|}{ Northwest Branch Anacostia River near Hyattsville, Md. (01651000) } \\
\hline 2005 & 57.1 & $\begin{array}{c}127,000 \\
(100,000-159,000)\end{array}$ & $\begin{array}{c}900 \\
(835-969)\end{array}$ & $\begin{array}{c}101 \\
(88-115)\end{array}$ & $\begin{array}{c}30,000 \\
(16,000-50,000)\end{array}$ \\
\hline 2006 & 77.2 & - & - & - & -- \\
\hline 2007 & 49.1 & $\begin{array}{c}66,400 \\
(49,800-86,700)\end{array}$ & $\begin{array}{c}613 \\
(550-682)\end{array}$ & $\begin{array}{c}62 \\
(52-73)\end{array}$ & $\begin{array}{c}13,000 \\
(7,600-21,000)\end{array}$ \\
\hline 2008 & 55.7 & -- & -- & -- & -- \\
\hline 2009 & 52.9 & $\begin{array}{c}141,000 \\
(992,00-196,000)\end{array}$ & $\begin{array}{c}788 \\
(729-849)\end{array}$ & $\begin{array}{c}89 \\
(77-103)\end{array}$ & $\begin{array}{c}26,000 \\
(16,000-40,000)\end{array}$ \\
\hline \multicolumn{6}{|c|}{ Rock Creek at Joyce Road, D.C. (01648010, Flow measured upstream at station 01648000) } \\
\hline 2008 & 57.6 & $\begin{array}{c}136,000 \\
(49,400-302,000)\end{array}$ & $\begin{array}{c}690 \\
(614-774)\end{array}$ & $\begin{array}{c}85 \\
(60-118)\end{array}$ & $\begin{array}{c}16,600 \\
(6,500-35,300)\end{array}$ \\
\hline 2009 & 59.9 & $\begin{array}{c}104,000 \\
(49,300-195,000)\end{array}$ & $\begin{array}{c}677 \\
(605-754)\end{array}$ & $\begin{array}{c}75 \\
(57-98)\end{array}$ & $\begin{array}{c}13,200 \\
(6.980-22,800)\end{array}$ \\
\hline 2010 & 85.4 & $\begin{array}{c}162,000 \\
(66,100-333,000)\end{array}$ & $\begin{array}{c}911 \\
(825-1,000)\end{array}$ & $\begin{array}{c}113 \\
(82-153)\end{array}$ & $\begin{array}{c}19,400 \\
(8,010-39,900)\end{array}$ \\
\hline 2011 & 70.4 & $\begin{array}{c}103,000 \\
(34,000-242,000)\end{array}$ & $\begin{array}{c}752 \\
(661-852)\end{array}$ & $\begin{array}{c}83 \\
(55-121)\end{array}$ & $\begin{array}{c}16,500 \\
(6,273-35,700)\end{array}$ \\
\hline
\end{tabular}


Some of the estimates of yields from this study were recalculated on a calendar-year basis (instead of the water-year basis that was used in tables 10 and 11) to compare to results from other studies and to provide some context for the variations between modeling approaches and periods of record (table 12). Because the annual cycles vary slightly, the yield estimates in table 12 based on calendar years are not comparable to those presented in table 11 based on water years. Langland and others (2012) have provided calendar-year loads for the Northwest Branch Anacostia River (data accessed on January 2, 2013 at http://cbrim.er.usgs.gov/). Differences between the yield estimates from the current study and those of Langland and others include: (1) data used by Langland and others were collected by the Maryland Department of Natural Resources for their CORE and TRENDS network using a center-of-flow grab sample with fixed-interval sampling and no autosampling or emphasis on storms; (2) under the CORE and TRENDS program, concentrations of SS were measured as total suspended solids (TSS), which are based on subsamples from a sampler, and have been shown to be biased low as opposed to whole-sample analysis (Horowitz, 1991; Gray and others, 2000); (3) Langland and others used the model ESTIMATOR to calculate loads based on mean daily values of flow and time, as compared to the current study, which used LOADEST that added turbidity and smaller time steps (hourly rather than daily); and (4) estimates by Langland and others were based on a longer period of record with 10 or more years of data. Comparisons between Langland's estimates and those of the current study are fairly consistent for TN and TP, but both the patterns and magnitudes of the SS loads are quite variable and do not compare well. The degree to which each source of variability has affected the modeling results has not been investigated for this report.

The second comparison study in table 12 was by Miller, Gutiérrez-Magness, and others (2007), which used similar sampling and modeling techniques to the current study. Previous estimates of yields in Miller, Gutiérrez-Magness, and others were slightly higher for SS than those in the current study, but within the bounds of the 95-percent confidence intervals, the yields are comparable. The estimates for TN and TP for both the Northeast and Northwest Branches of the Anacostia River actually compare quite well. Further, the earlier estimates by Miller, Gutiérrez-Magness, and others were based on only 2 years of data, which is less than optimal for calculations of annual loads (Yokum, 2000), so it is interesting that the results are close.

Langland estimated trends for the Northwest Branch Anacostia River separately for the 24-year span of the entire dataset and for the 10-year period from 2001-10. Results for the Northwest Branch station were similar to the general trend of other stations in the bay watershed with improvements (decreases) or insignificant trends in nitrogen loads but increasing trends for loads of phosphorus and sediment (as measured by TSS). The trend for nitrogen was only significant for the 24-year period of record, not for data collected over the last 10 years, indicating that a longer period of record is needed to detect subtle shifts in loads. Interestingly, the trend in phosphorus was not significant for the 24-year period, but has been degrading over the last 10 years, which may indicate non-linear behavior and possibly a shift in the trend. Comparison of Langland's results for Northwest Branch to the results of the current study is difficult given the lack of data, but qualitatively the patterns do not match, indicating that a longer period of data collection is necessary to make definitive, statistically significant conclusions about water-quality trends at these stations. 
Table 12. Comparison of estimates of calendar-year yields for the Northeast and Northwest Branches Anacostia River from different studies.

[Yields were calculated for calendar years (January to December) and are in units of kilograms/year/square kilometer; $\mathrm{ft}^{3} / \mathrm{s}$, cubic feet per second; --, not available]

\begin{tabular}{|c|c|c|c|c|c|c|c|}
\hline \multirow[b]{2}{*}{ Constituent } & \multirow[b]{2}{*}{ Year } & \multirow{2}{*}{$\begin{array}{c}\text { Langland }^{\mathbf{1}} \\
\text { ESTIMATOR } \\
\end{array}$} & \multicolumn{2}{|c|}{ This Study } & \multicolumn{2}{|c|}{ Miller $^{2}$} & \multirow{2}{*}{$\begin{array}{c}\text { Mean } \\
\text { Annual } \\
\text { Flow } \\
\mathrm{ft}^{3} / \mathrm{s} \\
\end{array}$} \\
\hline & & & LOADEST & ESTIMATOR & LOADEST & ESTIMATOR & \\
\hline \multicolumn{8}{|c|}{ Northwest Branch Anacostia River near Hyattsville, Md. (01651000) } \\
\hline \multirow{5}{*}{$\begin{array}{l}\text { Suspended } \\
\text { Sediment }\end{array}$} & 2005 & 31,900 & 188,870 & 217,000 & 248,000 & 233,000 & 57.1 \\
\hline & 2006 & 868,000 & -- & 411,000 & -- & -- & 77.2 \\
\hline & 2007 & 25,200 & -- & 48,300 & -- & -- & 49.1 \\
\hline & 2008 & 53,500 & -- & 118,000 & -- & -- & 55.7 \\
\hline & 2009 & 50,700 & 172,211 & 155,000 & -- & -- & 52.9 \\
\hline \multirow{5}{*}{$\begin{array}{c}\text { Total } \\
\text { Nitrogen }\end{array}$} & 2005 & 765 & 900 & 882 & 1,360 & 1,200 & 57.1 \\
\hline & 2006 & 1,220 & -- & 1,285 & -- & -- & 77.2 \\
\hline & 2007 & 634 & -- & 630 & -- & -- & 49.1 \\
\hline & 2008 & 797 & -- & 792 & -- & -- & 55.7 \\
\hline & 2009 & 758 & 788 & 773 & -- & -- & 52.9 \\
\hline \multirow{5}{*}{$\begin{array}{c}\text { Total } \\
\text { Phosphorus }\end{array}$} & 2005 & 80 & 147 & 162 & 161 & 161 & 57.1 \\
\hline & 2006 & 578 & -- & 191 & -- & -- & 77.2 \\
\hline & 2007 & 64 & -- & 48 & -- & -- & 49.1 \\
\hline & 2008 & 108 & -- & 89 & -- & -- & 55.7 \\
\hline & 2009 & 104 & 119 & 124 & -- & -- & 52.9 \\
\hline \multicolumn{8}{|c|}{ Northeast Branch Anacostia River at Riverdale, Md. (01649500) } \\
\hline \multirow{2}{*}{$\begin{array}{l}\text { Suspended } \\
\text { Sediment }\end{array}$} & 2004 & -- & 178,000 & 118,000 & 224,000 & 131,000 & 104 \\
\hline & 2005 & -- & 132,000 & 174,000 & 176,000 & 219,000 & 105 \\
\hline \multirow{2}{*}{$\begin{array}{c}\text { Total } \\
\text { Nitrogen }\end{array}$} & 2004 & -- & 982 & 951 & 962 & 959 & 104 \\
\hline & 2005 & -- & 876 & 953 & 976 & 1,010 & 105 \\
\hline \multirow{2}{*}{$\begin{array}{c}\text { Total } \\
\text { Phosphorus }\end{array}$} & 2004 & -- & 115 & 99 & 97 & 110 & 104 \\
\hline & 2005 & -- & 91 & 107 & 109 & 107 & 105 \\
\hline
\end{tabular}

${ }^{1}$ Langland and others (2012)

${ }^{2}$ Miller, Gutiérrez-Magness, and others (2007) 


\section{Summary}

Water-quality data were collected intermittently from 2003 to 2011 at four monitoring stations in the Anacostia River and Rock Creek watersheds: Northeast Branch Anacostia River at Riverdale, Maryland (USGS station 01649500); Northwest Branch Anacostia River near Hyattsville, Maryland (USGS station 01651000); Paint Branch near College Park, Maryland (USGS station 01649190); and Rock Creek at Joyce Road, Washington, D.C. (USGS station 01648010). The Anacostia River and Rock Creek are both tributaries to the Potomac River and the Chesapeake Bay, with watersheds in the urbanized corridor in and around Washington, D.C. Data collected during this study include discrete and continuous water-quality data, regression models to estimate concentrations and instantaneous loads of suspended sediment (SS), total nitrogen (TN), total phosphorus (TP), and E. coli bacteria from continuous physical parameters measured by multiparameter datasondes, and annual yields for SS, TN, TP, and E. coli.

Water-quality conditions in the Anacostia River were comparable within confidence intervals to those determined in previous studies on the Anacostia River. Concentrations of TN, TP, and SS were similar to other urban streams in the Chesapeake Bay watershed. There were strong seasonal patterns in the concentrations of SS, TN, TP, and bacteria, but it was not determined whether this was related to changes in sources in the watersheds, or seasonal shifts in hydrology. Concentrations in all four parameters, SS, TN, TP, and E. coli, were strongly correlated to flow, emphasizing the importance of storm-event sampling. Increases in numbers of bacteria during spring and summer months was certainly a direct result of increases in stream metabolism with higher temperatures, but sources of bacteria in urban watersheds can be highly variable over multiple time scales, and the effects of other sources of variability were not investigated in this study. Examples of sources of bacteria in urban streams include resuspension of residual materials in streambeds and storm drains, broken sewer lines, groundwater inputs from leaking sewer infrastructure, and runoff that carries pet and wildlife wastes. Data collected during the current study provided a baseline for conditions prior to implementation of multiple stormwater controls in the watersheds, and future data-collection efforts may provide indications of the efficacy of best management practices.

Multiple log-linear regression models were developed to estimate concentrations of nutrients, SS, and bacteria from continuous monitoring of physical parameters. Turbidity was the strongest predictive variable for all models. Coefficients of determination $\left(\mathrm{R}^{2}\right)$ were best for SS and TP models with values of 0.9 , and 0.8 to 0.9 , respectively. Models for $E$. coli bacteria were improved by adding temperature as a second predictive variable, and had $\mathrm{R}^{2}$ values of approximately 0.8 , but specific comparisons of model estimated values to discrete measured concentrations were not good due to hysteretic effects over the course of storms and to high variability in the measurements. Estimates of concentrations of TN had the lowest $\mathrm{R}^{2}$ values from 0.5 to 0.6.

Annual yields were estimated for SS, TN, TP, and E. coli bacteria using the U.S. Geological Survey model LOADEST with hourly time steps of turbidity, discharge, discharge ${ }^{2}$, time, time ${ }^{2}$, sin(time), and cos(time). Yields of SS, TN, and TP were similar to previous estimates in the Anacostia River and were within ranges found in other urban watersheds across the Chesapeake Bay Watershed. Ranges of estimates of annual yields for all four watersheds over the period of study were: SS (65,500 - 166,000 kilograms per year per square kilometer or $\left.\mathrm{kg} / \mathrm{yr} / \mathrm{km}^{2}\right)$, TN (465 - $\left.911 \mathrm{~kg} / \mathrm{yr} / \mathrm{km}^{2}\right)$, TP (36 - $\left.113 \mathrm{~kg} / \mathrm{yr} / \mathrm{km}^{2}\right)$, and E. coli bacteria (6.0 - 38 x $10^{12}$ viable colony-forming units per year per square kilometer). The study period was not long enough to determine trends for any of the constituents; however, results differed qualitatively from loads and trends determined by a previous study for the Northwest Branch Anacostia River station.

\section{Acknowledgments}

The authors thank the following people for their assistance and contributions to this study. Keith VanNess, Meo Curtis, and Steven Shofar of the Montgomery County Department of Environmental Protection have partnered with USGS to develop a strong monitoring network in Rock Creek and the Anacostia River. The cooperative relationship has supported new technologies and methods for enhanced datasets and better 
understanding of watershed processes. Water quality in the Northeast Branch Anacostia River has been monitored under a cooperative agreement with Dr. Mow-Soung Cheng of the Prince George’s County Department of Environmental Resources, providing a long-term dataset in an important urban stream in the Chesapeake Bay watershed. Excellent field support for data collection was provided by USGS hydrologic technicians Brenda Majedi, David Brower, Anthony Moduno, Michael Myrga, and Mitchell Donovan. The initial map of the study area was done by Mitchell Donovan. The authors thank Robert Shedlock, Charles Walker, Timothy Lathrop, Meo Curtis, and Keith VanNess for very thoughtful technical reviews that improved the quality of this report, Valerie Gaine and Kevin Breen for excellent editorial review, and Tim Auer for creative help with the final layout.

\section{References Cited}

Anderson, A.L., Miller, C.V., Olsen, L.D., Doheny, E.J., and Phelan, D.J., 2002, Water quality, sediment quality, and stream-channel classification of Rock Creek, Washington, D.C., 1999-2000, U.S. Geological Survey Water-Resources Investigations Report 02-4067, 91 p., accessed January 14, 2013 at http://md.water.usgs.gov/publications/wrir-02-4067/.

Bradu, D., and Mundlak, Y., 1970, Estimation in lognormal linear models: Journal of the American Statistical Association, v. 65, no. 329, p. 198-211.

Chanat, J.G., Miller, C.V., Bell, J.M., Majedi, B.F., and Brower, D.P., 2013, Summary and interpretation of discrete and continuous water-quality monitoring data, Mattawoman Creek, Charles County, Maryland, 200011, U.S. Geological Survey Scientific Investigations Report 2012-5265, 42 p. (also available online at http://pubs.usgs.gov/sir/2012/5265/).

Christensen, V.G., 2001, Characterization of surface-water quality based on real-time monitoring and regression analysis, Quivira National Wildlife Refuge, South-Central Kansas, December 1998 through June 2001: U.S. Geological Survey Water-Resources Investigations Report 01-4248, 28 p., accessed January 14, 2013 at http://ks.water.usgs.gov/pubs/reports/wrir.01-4248.html.

Christensen, V.G., Jian X., and Ziegler, A.C., 2000, Regression analysis and real-time water-quality monitoring to estimate constituent concentrations, loads, and yields in the Little Arkansas River, south-central Kansas, 1995-99: U.S. Geological Survey Water-Resources Investigations Report 00-4126, 36 p., accessed January 14, 2013 at $h t t p: / / k s . w a t e r . u s g s . g o v / p u b s /$ reports/wrir.00-4126.html.

Cohn, T.A. 1988, Adjusted maximum likelihood estimation of the moments of lognormal populations from type I censored samples: U.S. Geological Survey Open-File Report, 88-350, 34 p.

Cohn, T.A., 2005, Estimating contaminant loads in rivers: An application of adjusted maximum likelihood to type 1 censored data: Water Resources Research, v. 41, no. 7, W07003, doi:10.1029/2004WR003833, 13 p.

Cohn, T.A., Caulder, D.L., Gilroy, E.J., Zynjuk, L.D., and Summers, R.M., 1992, The validity of a simple statistical model for estimating fluvial constituent loads - An empirical study involving nutrient loads entering Chesapeake Bay: Water Resources Research, v. 28, no. 9, p. 2,353-2,363.

Cohn, T.A., Delong, L.L., Gilroy, E.J., Hirsch, R.M., and Wells, D.K., 1989, Estimating constituent loads: Water Resources Research, v. 25, no. 5, p. 937-942, DOI: 10.1029/WR025i005p00937.

Duan, N., 1983, Smearing Estimate: A nonparametric retransformation method, Journal of the American Statistical Association, v. 78, p. 605-610. 
Eckner, K.F., 1998, Comparison of membrane filtration and multiple-tube fermentation by the colilert and enterolert methods for detection of waterborne coliform bacteria, Escherichia coli, and enterococci used in drinking and bathing water quality monitoring in southern Sweden: Applied and Environmental Microbiology, v. 64, no. 8, p. 3,079-3,083.

Fishman, M.J., ed., 1993, Methods of analysis by the U.S. Geological Survey National Water Quality Laboratory - Determination of inorganic and organic constituents in water and fluvial sediments: U.S. Geological Survey Open-File Report 93-125, 217 p. (also available online at http://pubs.er.usgs.gov/publication/ofr93125).

Fry, J., Xian, G., Jin, S., Dewitz, J., Homer, C., Yang, L., Barnes, C., Herold, N., and Wickham, J., 2011, Completion of the 2006 National Land-Cover Database for the conterminous United States: Photogrammetric Engineering and Remote Sensing, v. 77, no. 9, p. 858-864.

Gray, J.R., Glysson, G.D., Turcios, L.M., Schwarz, G.E., 2000, Comparability of suspended-sediment concentration and total suspended solids data: U.S. Geological Survey Water-Resources Investigations Report 2000-4191, 14 p.

Helsel, D.R., and Hirsch, R.M., 1992, Statistical methods in water research: Amsterdam, Elsevier, 529 p.

Horowitz, A.J., 1991, A primer on sediment-trace-element chemistry (2d ed.): Chelsea, Michigan, Lewis Publishers, Inc., 136 p.

Jastram, J.D., Moyer, D.L., and Hyer, K.E., 2009, A comparison of turbidity-based and streamflow-based estimates of suspended-sediment concentrations in three Chesapeake Bay tributaries: U.S. Geological Survey Scientific Investigations Report 2009-5165, 37 p. (also available online at http://pubs.usgs.gov/sir/2009/5165/).

Jin, G., Englande, A.J., Bradford, H., and Jeng, H., 2004, Comparison of E. coli, enterococci, and fecal coliform as indicators for brackish water-quality assessment: Water Environment Research, v. 76, no. 3, p. 245-255.

Langland, M., Blomquist, J., Moyer, D., and Hyer, K, 2012, Nutrient and suspended-sediment trends, loads, and yields and development of an indicator of stream-water quality at nontidal sites in the Chesapeake Bay Watershed, 1985-2010: U.S. Geological Survey Scientific Investigations Report 2012-5093, 26 p. (also available online at $h t t p: / / p u b s . u s g s . g o v / s i r / 2012 / 5093 /)$.

Langland, M.J., Raffensperger, J.P., Moyer, D.L., Landwehr, J.M., and Schwarz, G.E., 2006, Changes in streamflow and water quality in selected nontidal basins in the Chesapeake Bay Watershed, 1985-2004: U.S. Geological Survey Scientific Investigations Report 2006-5178, 75 p. plus appendixes (also available online at http://pubs.usgs.gov/sir/2006/5178/).

Maryland Department of the Environment, 2007a, Total maximum daily loads of fecal bacteria for the nontidal Rock Creek Basin in Montgomery County, Maryland: Final, 80 p., accessed January 2, 2013 at http://www.mde.maryland.gov/programs/Water/TMDL/ApprovedFinalTMDLs/Documents/www.mde.state.md.u s/assets/document/Rock_Creek_TMDL_060607_final.pdf.

Maryland Department of the Environment, 2007b, Total maximum daily loads of sediment/ total suspended solids for the Anacostia River Basin, Montgomery and Prince George’s Counties, Maryland and the District of Columbia: Final, 54 p. plus appendixes, accessed January 2, 2013 at http://www.mde.maryland.gov/programs/water/tmdl/approvedfinaltmdls/pages/programs/waterprograms/tmdl/ approvedfinaltmdl/tmdl_final_anacostia_sediment.aspx. 
Maryland Department of the Environment, 2008a, Total maximum daily loads of nutrients/ biochemical oxygen demand for the Anacostia River Basin, Montgomery and Prince George's Counties, Maryland and the District of Columbia: Final, 60 p. plus appendixes, accessed January 2, 2013 at http://www.mde.maryland.gov/programs/water/tmdl/approvedfinaltmdls/pages/programs/waterprograms/tmdl/ approvedfinaltmdl/tmdl_final_anacostia_nutrients.aspx.

Maryland Department of the Environment, 2008b, Total maximum daily loads of fecal bacteria for the Anacostia River Basin in Montgomery and Prince George’s Counties, Maryland and the District of Columbia-Final, 123 p., accessed January 2, 2013 at http://www.mde.maryland.gov/programs/Water/TMDL/ApprovedFinalTMDLs/Documents/www.mde.state.md.u s/assets/document/Anacostia_fc_TMDL_101106_final.pdf.

Maryland Department of the Environment, 2011, Total maximum daily load of sediment in the Rock Creek watershed, Montgomery County, Maryland-Final, 49 p., accessed January 2, 2013 at http://www.mde.maryland.gov/programs/Water/TMDL/ApprovedFinalTMDLs/Documents/www.mde.state.md.u s/assets/document/Rock_Sed_TMDL_092911_Final.pdf.

Maryland Department of the Environment, 2012, Total maximum daily load of phosphorus in the Rock Creek watershed, Montgomery County, Maryland-Draft, 46 p., accessed January 2, 2013 at http://www.mde.maryland.gov/programs/water/tmdl/drafttmdlforpubliccomment/documents/www.mde.state.md .us/assets/document/rock_creek_nuttmdl_pn_071012.pdf.

Maryland Department of the Environment, 2012, Maryland's final 2012 integrated report of surface-water quality, 125 p. accessed January 2, 2013 at http://www.mde.state.md.us/programs/Water/TMDL/Integrated303dReports/Pages/2012_IR.aspx.

Miller, C.V., Gutiérrez-Magness, A.L., Feit Majedi, B.L., and Foster, G.D., 2007, Water quality in the Upper Anacostia River, Maryland: Continuous and discrete monitoring with simulations to estimate concentrations and yields, 2003-05: U.S. Geological Survey Scientific Investigations Report 2007-5142, 43 p. (also available online at $h t t p: / / p u b s . u s g s . g o v / s i r / 2007 / 5142 /)$.

Miller, C.V., Weyers, H.S., Blazer, V.S., and Freeman, M.E., 2006, Chemical and ecological health of white sucker (Catostomus commersoni) in Rock Creek Park, Washington, D.C., 2003-04: U.S. Geological Survey Scientific Investigations Report 2006-5140, 37 p. (also available online at http://pubs.usgs.gov/sir/2006/5140/).

Montgomery County Department of Environmental Protection, 2012a, Rock Creek implementation plan, prepared by Biohabitats Inc., 40 p., accessed January 2, 2013, at http://www6.montgomerycountymd.gov/content/dep/downloads/water/RockCreekWIP_FINAL.pdf.

Montgomery County Department of Environmental Protection, 2012b, Anacostia watershed implementation plan, prepared by Biohabitats Inc., 51 p., accessed January 2, 2013, at http://www6.montgomerycountymd.gov/content/dep/downloads/water/AnacostiaRiverWIP_FINAL.pdf.

Patton, C.J., and Truitt, E.P., 2000, Methods of analysis by the U.S. Geological Survey National Water Quality Laboratory - Determination of ammonium plus organic nitrogen by a Kjeldahl digestion method and an automated photometric finish that includes digest cleanup by gas diffusion: U.S. Geological Survey Open-File Report 00-170, 31 p., accessed January 13, 2013 at http://nwql.usgs.gov/Public/pubs/OFR00-170/OFR00170.html. 
Phelan, D.J., and Miller, C.V., 2010, Occurrence and distribution of organic wastewater compounds in Rock Creek Park, Washington, D.C., 2007-08: U.S. Geological Survey Scientific Investigations Report 2010-5162, 68 p. (also available online at http://pubs.usgs.gov/sir/2010/5162/).

Rasmussen, T.J., and Ziegler, A.C., 2003, Comparison and continuous estimates of fecal coliform and Escherichia coli bacteria in selected Kansas streams, May 1999 through April 2002: U.S. Geological Survey Water-Resources Investigations Report 03-4056, 80 p., accessed January 13, 2013 at http://ks.water.usgs.gov/pubs/abstracts/wrir.abstract.03-4056.html.

Rasmussen, T.J., Ziegler, A.C., and Rasmussen, P.P., 2005, Estimation of constituent concentrations, densities, loads, and yields in lower Kansas River, northeast Kansas, using regression models and continuous waterquality monitoring, January 2000 through December 2003: U.S. Geological Survey Scientific Investigations Report 2005-5165, 117 p. (also available online at http://pubs.usgs.gov/sir/2005/5165/).

Runkel, R.L., Crawford, C.G., and Cohn, T.A., 2004, Load Estimator (LOADEST): A FORTRAN program for estimating constituent loads in streams and rivers: U.S. Geological Survey Techniques and Methods book 4, chap. A5, 69 p., available online only at http://pubs.usgs.gov/tm/2005/tm4A5/.

Shreve, E.A., and Downs A.C., 2005, Quality-assurance plan for the analysis of fluvial sediment by the U.S. Geological Survey Kentucky Water Science Center Sediment Laboratory: U.S. Geological Survey Open-File Report 2005-1230, 28 p. (also available online at http://pubs.usgs.gov/of/2005/1230/).

TIBCO Corporation, 2008, TIBCO Spotfire S+ 8.1 for Windows Users® Guide: TIBCO Corporation, 582 p.

U.S. Army Corps of Engineers (USACE), 2010, Anacostia River watershed restoration plan and report, final draft, accessed January 2, 2013, at http://www.anacostia.net/Restoration_Plan/download/Anacostia-ReportWeb-Quality.pdf.

U.S. Environmental Protection Agency (USEPA), 2010, Chesapeake Bay total maximum daily loads for nitrogen, phosphorus, and sediment, Section 9 - Chesapeake Bay TMDLs, 34 p., accessed January 2, 2013 at http://www.epa.gov/reg3wapd/tmdl/ChesapeakeBay/tmdlexec.html.

U.S. Geological Survey, variously dated, National field manual for the collection of water-quality data: U.S. Geological Survey Techniques of Water-Resources Investigations, book 9, chaps. A1-A9, available online at http://water.usgs.gov/owq/FieldManual/index.html.

Wagner, R.J., Boulger, R.W., Oblinger, C.J., and Smith, B.E., 2006, Guidelines and standard procedures for continuous water-quality monitors: station operation, calibration, record computation, and data reporting: U.S. Geological Survey Techniques and Methods 1-D3, 96 p. (also available online at http://pubs.usgs.gov/tm/2006/tm1D3/).

Yokum, S.E., 2000, A revised load estimation procedure for the Susquehanna, Potomac, Patuxent, and Choptank Rivers: U.S. Geological Survey Water-Resources Investigations Report 00-4156, 49 p. (also available online at http://pubs.usgs.gov/wri/wri00-4156/). 

For additional information, contact:

Director, MD-DE-DC Water Science Center

U.S. Geological Survey

5522 Research Park Drive

Baltimore, MD 21228

or visit our Web site at: http://md.water.usgs.gov 
